\title{
Emerging new roles of the lysosome and neuronal ceroid lipofuscinoses
}

\author{
Anil B. Mukherjee ${ }^{1 *}$ D, Abhilash P. Appu', Tamal Sadhukhan', Sydney Casey ${ }^{1}$, Avisek Mondal', \\ Zhongjian Zhang ${ }^{1,2}$ and Maria B. Bagh ${ }^{1 *}$
}

\begin{abstract}
Neuronal Ceroid Lipofuscinoses (NCLs), commonly known as Batten disease, constitute a group of the most prevalent neurodegenerative lysosomal storage disorders (LSDs). Mutations in at least 13 different genes (called CLNs) cause various forms of NCLs. Clinically, the NCLs manifest early impairment of vision, progressive decline in cognitive and motor functions, seizures and a shortened lifespan. At the cellular level, all NCLs show intracellular accumulation of autofluorescent material (called ceroid) and progressive neuron loss. Despite intense studies the normal physiological functions of each of the CLN genes remain poorly understood. Consequently, the development of mechanism-based therapeutic strategies remains challenging. Endolysosomal dysfunction contributes to pathogenesis of virtually all LSDs. Studies within the past decade have drastically changed the notion that the lysosomes are merely the terminal degradative organelles. The emerging new roles of the lysosome include its central role in nutrient-dependent signal transduction regulating metabolism and cellular proliferation or quiescence. In this review, we first provide a brief overview of the endolysosomal and autophagic pathways, lysosomal acidification and endosome-lysosome and autophagosome-lysosome fusions. We emphasize the importance of these processes as their dysregulation leads to pathogenesis of many LSDs including the NCLs. We also describe what is currently known about each of the 13 CLN genes and their products and how understanding the emerging new roles of the lysosome may clarify the underlying pathogenic mechanisms of the NCLs. Finally, we discuss the current and emerging therapeutic strategies for various NCLs.
\end{abstract}

Keywords: Neurodegeneration, Neuronal Ceroid Lipofuscinosis, Batten Disease, Lysosomal Storage Disease

\section{Background}

In 1955, Christian de Duve, while investigating the mechanism of insulin action, discovered the lysosome [1], a membrane-bound organelle which plays critical roles in the degradation and recycling of material delivered to it from both extracellular and intracellular sources [2-4]. Although historically known as the center for cellular waste disposal, the lysosome has since been reported to serve essential roles in such functions as cellular nutrient sensing, energy metabolism and plasma membrane repair. To maintain homeostasis, a network of lysosomal proteins, soluble lysosomal acid hydrolases, lysosome-related organelles, autophagosomes and other

\footnotetext{
*Correspondence: mukherja@exchange.nih.gov; baghmb@mail.nih.gov 'Section on Developmental Genetics, Program on Endocrinology and Molecular Genetics, Eunice Kennedy Shriver National Institute of Child Health and Human Development, The National Institutes of Health, Bethesda, Maryland 20892-1830, USA

Full list of author information is available at the end of the article
}

cellular constituents are put in place to degrade the material imported into the cell. Impairment of this lysosomal network contributes to a group of diseases called LSDs [5-7]. In most of the LSDs, neurodegeneration is a devastating manifestation [8]. Despite tremendous advances in the field, the precise molecular mechanism(s) underlying these diseases remain elusive. The emerging new roles of the lysosome as the nutrient sensor and signaling hub of the cell may provide a better understanding of the pathophysiology of various NCLs.

The lysosome, in addition to harboring the soluble acid hydrolases in its lumen, is endowed with numerous proteins that are localized to its membrane $[9,10]$. For a long time, the lysosomal membrane was thought to provide just a barrier between the luminal acid hydrolases and the cytoplasm. However, emerging evidence indicates that the lysosomal membrane serves critical roles in a wide range of cellular functions, including 
phagocytosis, autophagy, membrane repair and apoptosis [10]. All lysosomal membrane proteins are synthesized in the endoplasmic reticulum (ER) and are selectively transported to the lysosome. The degradative functions of the lysosome are essential for cell clearance, signaling, metabolism and homeostasis. Cellular homeostasis also requires ubiquitylation, a process that facilitates specifying the proteins which are transported to the lysosomal lumen by endosomal sorting complex required for transport (ESCRT) to sort cargos tagged with ubiquitin into the invaginated endosomal membranes [11]. Recently, it has been reported that the ESCRT machinery plays an essential role in repairing injured endolysosomes and thereby providing a mechanism to protect the cells from death.

Compelling evidence indicates that the lysosome performs a much broader function than just being the cellular waste disposal. It has critical roles in some of the most vital processes like secretion, signaling, repair of the plasma membrane, and energy metabolism [12]. In addition, the lysosome has an essential role in autophagy $[3,4]$, which along with its other functions places this organelle at the center of several vital processes, such as nutrient sensing, metabolism and homeostasis [13]. Thus, impairment of lysosomal function has implications for the pathogenesis of all LSDs including the NCLs.

Lysosomes receive materials for degradation via three major pathways: phagocytosis, endocytosis and autophagy (Fig. 1). A network of lysosomal proteins, and other cellular constituents contribute to the degradation of the imported cargo delivered to this organelle [14]. In the following paragraphs, we articulate how the endolysosomal and autophagic pathways of degradation require lysosomal acidification and endosome-lysosome as well as autophagosome-lysosome fusions.

\section{The endolysosomal and autophagic pathways of degradation}

The lysosome is the terminal organelle for degradation and cellular clearance. Materials from varying locations are delivered to the lysosome for degradation. There are two major pathways by which materials enter the lysosome. These are (i) endocytosis in which the material from outside the cell enters the lysosome via endocytic

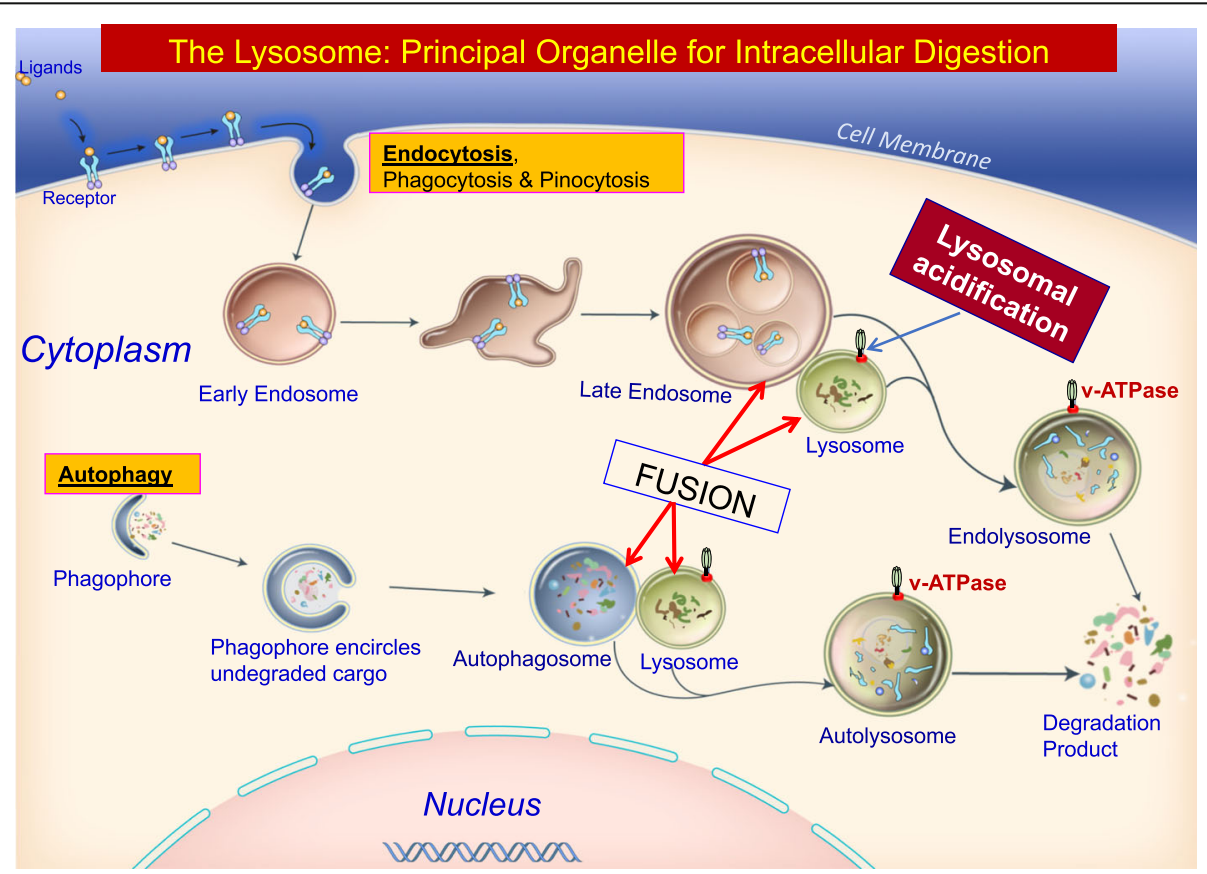

Fig. 1 Dysregulation of the endocytic and autophagic pathways in LSDs including the NCLs. Cells import materials from outside the cell by endocytosis. This process is initiated by the invagination of the plasma membrane, which encloses the material forming the early endosome, which progresses to the late endosome. The fusion of the membranes of the late endosome and lysosome forms a hybrid structure called endolysosome. The fusion of the two membranes is catalyzed by Rab7, a small GTPase, and the endosomal cargo is degraded by lysosomal acid hydrolases and the constituent components are reutilized by the cell. The process of autophagy is initiated by the formation of a doublemembrane structure in the cytoplasm called phagophore. This structure in its mature form is called phagosome, which encircles materials such as aged macromolecules and disabled organelles. The autophagosome fuses with the lysosome forming a hybrid structure called autolysosome. The lysosomal hydrolases then degrade the cargo to their respective components (i.e. amino acids for proteins, fatty acids for lipids, etc.) which are reutilized by the cells. Notably, impaired or missing lysosomal acid hydrolases or failure of endosome-lysosome and autophagosomelysosome fusions may result in the accumulation of undigested cargo in the lysosome leading to lysosomal storage diseases 
vesicles originating from the plasma membrane [15] and (ii) autophagy in which material from within the cell is transported to the lysosome via autophagosomes. It has been suggested that dysregulation of autophagy is a common mechanism in the pathogenesis of the LSDs including several NCLs and other more common neurodegenerative diseases [16].

The endo-lysosomal pathway plays multiple roles in cellular function and homeostasis [17, 18]. This pathway has an important function in enabling the cell to internalize extracellular macromolecules and fluids together with portions of the plasma membrane. It also plays vital roles in the sorting of the internalized membrane and its constituent proteins. The major sorting stations in this pathway consist of the early and late endosomes and pleiomorphic organelles with tubulo-cisternal and multi-vesicular domains, which are packed with intraluminal vesicles [19]. The cargo contained in the endosomes are either delivered to the lysosome where acid hydrolases catalyze degradation or promote recycling back to the plasma membrane via recycling endosomes, or further transported to the Golgi using the retromer complex [20, 21]. In some instances, the endosomes undergo fusion with the plasma membrane, thereby discharging the contents into the extracellular space. These extracellular materials are called the exosomes [22].

The Rab GTPases [23], which are the major regulators of vesicular trafficking, control the dynamics of sorting, trafficking and membrane remodeling in the endocytic pathway including secretion of the exosomes. Recent investigations have demonstrated how Rab35 and Arf6 might serve as input sensors for two types of endocytosis to balance membrane trafficking to preserve cell surface homeostasis. More recently, it has been shown that lysosomal contact with mitochondria regulates mitochondrial fission through the hydrolysis of Rab7, which allows bidirectional regulation of mitochondrial-lysosomal dynamics [24]. This may explain why lysosomal as well as mitochondrial dysfunction have been observed in various human diseases including the neurodegenerative LSDs like the NCLs. One of the important factors in intracellular digestion is lysosomal acidification, which directly impacts the catalytic activities of the lysosomal acid hydrolases as these enzymes work most efficiently in acidic $\mathrm{pH}$.

\section{Lysosomal acidification}

In virtually all NCLs, except CLN2 and CLN8, lysosomal acidification is reported to be dysregulated $[25,26]$. It has also long been recognized that acidification of the endocytic organelles is essential for the degradation and clearance of exogenous and endogenous material delivered to the lysosome via endosome and autophagosome pathways [15]. Lysosomal acidification is regulated by vacuolar ATPase (v-ATPase) [27-29], which is a multi-subunit protein complex consisting of a cytosolic V1-sector and a lysosomal membrane-anchored V0-sector. The v-ATPase acidifies a wide array of intracellular organelles by pumping protons across the membranes into the vesicular (late endosomal/lysosomal) lumen [27-29]. The V1-sector of v-ATPase generates energy by hydrolyzing ATP and this energy is utilized to facilitate the transport of protons from the cytoplasm across the lysosomal-membranes to the vesicular lumen. The recycling of the cell surface receptors, the receptor-ligand dissociation, protein degradation by lysosomal hydrolases, neurotransmitter loading as well as the recycling of synaptic vesicles are all $\mathrm{pH}$-dependent $[30,31]$. Moreover, it has been demonstrated that alterations in the intracellular $\mathrm{pH}$ alone severely alter organellar morphology, movement and function [32]. Indeed, it has been demonstrated that nanoparticle-mediated correction of lysosomal acidification defects may have implications for lysosomalrelated diseases [33].

\section{The endosome-lysosome and autophagosome-lysosome fusion}

An orderly execution of fusion of the membranous organelles is vitally important for the eukaryotic cells [34]. For example, the fusion of the autophagosome-lysosome and endosome-lysosome membranes is critical for the degradation of material imported from intracellular and extracellular sources that are delivered to the lysosome [4]. Similarly, membrane fusion plays an essential role in synaptic transmission in the central nervous system in which SNARE- and SM (Sec1/Munc18-like)-proteins have been reported to play critical roles [35]. The v-ATPase, by regulating lysosomal acidification, mediates the fusion of endocytic and autophagic vesicles although the mechanism(s) by which the fusion of these membranes occurs remains poorly understood [36]. Notably, the maturation of the autophagosome precursor has been shown to depend on homotypic membrane fusions [37].

Autophagy is a major degradative pathway in the cell $[3,4]$. There are three different types of autophagy: (i) macroautophagy, (ii) microautophagy and (iii) chaperone -mediated autophagy. During macroautophagy (hereafter called autophagy), the cytoplasmic contents (e.g. long-lived proteins and disabled or aged organelles) are encircled by a double-membrane structure called the autophagosome [3, 4]. An autophagosome is a doublemembrane structure, originating from the ER-mito chondria contact sites, called a phagophore, which encloses long-lived proteins, aged and disabled organelles, and aggregated proteins. Autophagosome fuses with the lysosomal membrane generating a hybrid organelle called autolysosome in which the acid hydrolases degrade the cargo. At the final stage of cargo-degradation, each type of autophagy requires the fusion of 
autophagosomes with functional lysosomes [38]. In recent comprehensive reviews $[39,40]$ the molecular definition of autophagy and autophagy-related processes as well as how their dysfunction may lead to neurodegeneration has been described. It has become increasingly evident that impaired autophagy is associated with several human neurodegenerative diseases including neurodegenerative LSDs like the NCLs [16, 40, 41]. Membrane fusion is an essential requirement for early biogenesis of autophagosome and degradation of cargo in the lysosome and this vital process is impaired in many neurodegenerative diseases $[4,40,42]$.

Impaired membrane fusions have been reported in the LSDs as well as in common neurodegenerative diseases $[43,44]$. Thus, fusion of these organelles is particularly important for maintaining neuronal survival as impaired autophagy causes accumulation of several aggregate-prone proteins (e.g. huntingtin, $\alpha$-synuclein), which are potentially harmful to the neurons $[44,45]$. Despite intense investigations the physiological functions of the mutant genes underlying various forms of the NCLs remain poorly understood. In the following paragraphs, we describe what is known about these genes, the proteins they encode and how the emerging new roles of the lysosome may advance our understanding as to how mutations in these genes may impair lysosomal function.

\section{CLN gene mutations and their differential pathologic manifestations in various NCLs}

Commonly known as Batten disease [46-52], NCLs constitute a group of the most common inherited neurodegenerative LSDs that mostly affect children. Lysosomal accumulation of autofluorescent material (called ceroid), increased neuronal apoptosis, dysregulated autophagy, neurodegeneration and shortened lifespan are some of the common features shared by all NCLs. Our knowledge that the lysosome functions as a nutrient sensor and the signaling hub of the cell [12-14, 53-56] may be applied to facilitate a greater understanding of the pathogenic mechanism(s) underlying the NCLs.

The 13 different genes (Table 1), mutations of which cause various forms of NCLs, may be classified into four groups according to the proteins they encode. The group I genes (CLN1, CLN2 CLN5, CLN10 and CLN13) encode lysosomal soluble proteins/enzymes. The group II genes (CLN3, CLN7 and CLN12) encode membrane proteins but two of the genes (CLN6 and CLN8) encode ER-membrane proteins. The group III genes (CLN4 and CLN14) encode soluble proteins and one gene in group IV (CLN11) encodes a protein in the secretory pathway [46-52]. A summary of the proteins encoded by all CLN genes is provided in Table 1. In Table 2, The CLN gene mutantions underlying pathophysiological manifestations of various NCL forms are provided in Table 2.

\section{CLN1/PPT1}

The discovery of an enzyme in bovine brain, its purification to homogeneity and the demonstration that it catalyzed the cleavage of the thioester linkage in palmitoyl-CoA and S-acylated H-Ras in vitro [57] paved the way for the identification of the mutant gene (now called CLN1) [58]. Inactivating mutations in the CLN1 gene underlie infantile NCL (or INCL), also known as Santavuori-Haltia disease [59]. The CLN1 gene encodes palmitoyl-protein thioesterases-1 (PPT1) [60], a soluble depalmitoylating enzyme, which is essential for the degradation of S-acylated proteins by lysosomal hydrolases [61]. Numerous proteins in the central nervous system undergo S-palmitoylation (or S-acylation), a process in which a 16-carbon fatty acid (predominantly palmitate) is attached to specific cysteine residues in polypeptides via thioester linkage [62]. It is the only reversible lipid modification that has emerged as an important regulatory mechanism for many proteins, especially in the brain $[63,64]$. These S-acylated proteins require depalmitoylation by thioesterases prior to degradation by lysosomal acid hydrolases [61]. Thus, PPT1-deficiency impairs lysosomal degradative function causing intracellular accumulation of $\mathrm{S}$-acylated proteins leading to INCL. At birth, the children afflicted with INCL are phenotypically normal. However, by 11-18 months of age they manifest signs of psychomotor retardation. By 2 years of age, these children are completely blind due to retinal degeneration. Around 4 years of age, an isoelectric electroencephalogram (EEG) attests to a vegetative state, which may last for several more years before eventual death [59].

It has been reported that CLN1 mutations can also cause milder forms of INCL, which may manifest as late infantile, juvenile, or adult phenotypes $[65,66]$. Although the precise biological roles of PPT1 and its in vivo substrates remain unidentified, a recent report suggested that cysteine string protein- $\alpha(\mathrm{CSP} \alpha)$ may be an in vivo substrate of PPT1 [67]. Notably, it has been demonstrated that in vitro, PPT1 depalmitoylates S-acylated growth associated protein 43 (GAP-43) and rhodopsin and its catalytic activity is higher at neutral $\mathrm{pH}$ (7.4) rather than at acidic $\mathrm{pH}(4.0)$ suggesting that PPT1 may have extra-lysosomal functions. Altered lysosomal $\mathrm{pH}$ has been reported in several NCLs including INCL [68]. It has recently been demonstrated that in $\mathrm{Cln}^{-1-}$ mice, V0a1, a critical subunit of the V-ATPase (the proton pump of the cell) that regulates lysosomal acidification, requires S-palmitoylation for its lysosomal targeting [68]. Notably, in $\mathrm{Cln}^{-/-}$mice lacking Ppt1, V0a1 is misrouted to the plasma membrane instead of its normal localization on the lysosomal membrane (Fig. 2). This defect inhibits v-ATPase activity and consequently, alters the lysosomal pH in Ppt1-deficient cells [68]. 
Table 1 Neuronal Ceroid Lipofuscinoses (Batten Disease)

\begin{tabular}{|c|c|c|c|c|c|c|c|}
\hline $\begin{array}{l}\text { Mutant } \\
\text { Gene }\end{array}$ & $\begin{array}{l}\mathrm{NCL} \\
\text { Disease }\end{array}$ & $\begin{array}{l}\text { Encoded } \\
\text { Protein }\end{array}$ & $\begin{array}{l}\text { Classification } \\
\text { and protein } \\
\text { size }\end{array}$ & $\begin{array}{l}\text { Posttranslational } \\
\text { modification }\end{array}$ & $\begin{array}{l}\text { Subcellular } \\
\text { localization }\end{array}$ & Function & Interactions \\
\hline CLN1 & $\begin{array}{l}\text { Infantile } \\
\mathrm{NCL}(C L N 1- \\
\text { disease) }\end{array}$ & $\begin{array}{l}\text { Palmitoyl } \\
\text { protein } \\
\text { thioesterase } 1 \\
\text { (PPT1) }\end{array}$ & $\begin{array}{l}\text { soluble protein, } \\
306 \text { aa }\end{array}$ & $\begin{array}{l}\text { N-gly } \\
\text { M6P }\end{array}$ & $\begin{array}{l}\text { Lysosomal } \\
\text { lumen, } \\
\text { extralysosomal } \\
\text { vesicules, } \\
\text { extracellular, } \\
\text { presynaptic } \\
\text { areas in neurons }\end{array}$ & $\begin{array}{l}\text { Palmitoy-protein } \\
\text { Ithioesterase }\end{array}$ & $\begin{array}{l}\text { S-acetylated proteins } \\
\text { (GAP43, rhodopsin, } \\
\text { saposin D) }\end{array}$ \\
\hline CLN2 & $\begin{array}{l}\text { Late } \\
\text { infantile } \\
\mathrm{NCL}\end{array}$ & $\begin{array}{l}\text { Tripeptidyl } \\
\text { peptidase } 1 \\
\text { (TPP1) }\end{array}$ & $\begin{array}{l}\text { soluble protein, } \\
563 \text { aa }\end{array}$ & $\begin{array}{l}\text { N-gly } \\
\text { M6P }\end{array}$ & $\begin{array}{l}\text { Lysosomal } \\
\text { lumen }\end{array}$ & Serine protease & CLN3, CLN5 \\
\hline CLN3 & $\begin{array}{l}\text { Juvenile } \\
\mathrm{NCL} \text {, } \\
\text { Batten } \\
\text { disease }\end{array}$ & CLN3/Batenin & $\begin{array}{l}6 \text { TM protein, } \\
438 \text { aa }\end{array}$ & $\begin{array}{l}\text { N-gly } \\
\text { farnesylated } \\
\text { phosphorylated }\end{array}$ & $\begin{array}{l}\text { Late endosomal/ } \\
\text { lysosomal } \\
\text { membrane, } \\
\text { presynaptic } \\
\text { vesicles }\end{array}$ & $\begin{array}{l}\text { Unknown / predicted: pH } \\
\text { regulation and } \\
\text { modulation of vesicular } \\
\text { trafficking and fusion }\end{array}$ & $\begin{array}{l}\text { Hook1, kinesin-2, CLN5, } \\
\text { Na+, K+ ATPase, Rab7, } \\
\text { fodrin }\end{array}$ \\
\hline CLN4 & $\begin{array}{l}\text { Kuffs } \\
\text { disease }\end{array}$ & $\begin{array}{l}\text { Cysteine-string } \\
\text { protein alpha } \\
\text { (CSPa), DNAJC5 }\end{array}$ & $\begin{array}{l}\text { soluble protein, } \\
198 \text { aa }\end{array}$ & Palmitoylated & $\begin{array}{l}\text { Cytosolic, } \\
\text { vesicular } \\
\text { membranes }\end{array}$ & $\begin{array}{l}\text { Hsc70 co-chaperone } \\
\text { involved in exocytosis } \\
\text { and endocytosis }\end{array}$ & $\begin{array}{l}\text { CSPa, SNAP-25, myosin } \\
\text { IIB, calsenilin, DHHC17, } \\
\text { dynamin-1, syntaxin, Gas, } \\
\text { Rab3b, synaptotagmin 9, } \\
\text { Hsp70, Hsp40, Hsp90, HIP, } \\
\text { HOP, SGT }\end{array}$ \\
\hline CLN5 & $\begin{array}{l}\text { CLN5 } \\
\text { disease }\end{array}$ & - & $\begin{array}{l}\text { soluble protein, } \\
407 \text { aa }\end{array}$ & $\begin{array}{l}\text { N-gly } \\
\text { M6P }\end{array}$ & $\begin{array}{l}\text { Lysosomal } \\
\text { lumen }\end{array}$ & $\begin{array}{l}\text { Unknown / predicted: } \\
\text { modulation of vesicular } \\
\text { trafficking }\end{array}$ & $\begin{array}{l}\text { PPT1/CLN1, TPP1/CLN2, } \\
\text { CLN3, CLN6, CLN8 }\end{array}$ \\
\hline CLN6 & $\begin{array}{l}\text { CLN6 } \\
\text { disease }\end{array}$ & CLN6-protein & $\begin{array}{l}7 \text { TM protein, } \\
311 \text { aa }\end{array}$ & None & $\begin{array}{l}\text { ER-membrane } \\
\text { (transmembrane) }\end{array}$ & Unknown & $\begin{array}{l}\text { CLN5, CLN6 } \\
\text { CRMP-2 }\end{array}$ \\
\hline CLN7 & $\begin{array}{l}\text { Turkish } \\
\text { variant of } \\
\text { late- } \\
\text { infantile } \\
\mathrm{NCL}\end{array}$ & MFSD8 & $\begin{array}{l}12 \mathrm{TM} \text { protein, } \\
518 \mathrm{aa}\end{array}$ & $\begin{array}{l}\mathrm{N} \text {-gly } \\
\text { proteolytic } \\
\text { cleaved }\end{array}$ & $\begin{array}{l}\text { Lysosomal } \\
\text { membrane }\end{array}$ & $\begin{array}{l}\text { Predicted transmembrane } \\
\text { transporter function } \\
\text { predicted }\end{array}$ & AP-1, cathepsin L \\
\hline CLN8 & $\mathrm{NCL} 8$ & CLN8 & $\begin{array}{l}5 \text { TM protein, } \\
286 \text { aa }\end{array}$ & None & $\begin{array}{l}\text { ER-membrane } \\
\text { (transmembrane) }\end{array}$ & $\begin{array}{l}\text { Unknown, predicted: to } \\
\text { aid in the maturation of } \\
\text { lysosomal proteins by } \\
\text { transporting them from } \\
\text { the ER to the Golgi } \\
\text { complex, predicted } \\
\text { regulation in lipid } \\
\text { metabolism, }\end{array}$ & $\begin{array}{l}\text { CLN5, CLN8, syntaxin 8, } \\
\text { VAPA, GATE16, AGA, } \\
\text { ARSA, ARSB, ARSG, CTBS, } \\
\text { CTSA, CTSB, CTSD, CTSF, } \\
\text { CTSZ, DNASE2, GALNS, } \\
\text { GGH, GM2A, GNS, GUSB, } \\
\text { HPSE, IDS, LIPA, MAN2B1, } \\
\text { MAN2B2, MPO, NAGA, } \\
\text { NEU1, PCYOX1, PLBD2, } \\
\text { PPT1, PPT2, PSAP, } \\
\text { RNASET2, SGSH, SIAW, } \\
\text { SMPD1, TPP1 }\end{array}$ \\
\hline CLN9 & - & $\begin{array}{l}\text { Currently } \\
\text { designated as } \\
\text { CLN4 }\end{array}$ & - & - & - & - & - \\
\hline CLN10 & $\begin{array}{l}\text { Congenital } \\
\mathrm{NCL}\end{array}$ & $\begin{array}{l}\text { Cathepsin D } \\
\text { (CTSD) }\end{array}$ & $\begin{array}{l}\text { soluble protein, } \\
462 \text { aa }\end{array}$ & $\begin{array}{l}\text { N-gly } \\
\text { M6P }\end{array}$ & $\begin{array}{l}\text { Lysosomal } \\
\text { lumen }\end{array}$ & Aspartyl protease & $\begin{array}{l}\text { APP, CST3, CTSB, proSAP, } \\
\text { and several others }\end{array}$ \\
\hline CLN11 & Unknown & $\begin{array}{l}\text { Progranulin } \\
\text { and granulins }\end{array}$ & $\begin{array}{l}\text { soluble protein, } \\
593 \text { aa }\end{array}$ & None & Extracellular & $\begin{array}{l}\text { Unknown/ predicted, } \\
\text { roles in inflammation, } \\
\text { embryogenesis, cell } \\
\text { motility and } \\
\text { tumorigenesis }\end{array}$ & $\begin{array}{l}\text { MMPs, ADAMs, TGFa } \\
\text { receptors, sortilin, } \\
\text { ADAMTS-7/ADAMTS-12/ } \\
\text { perlecan/HDL/COMP, } \\
\text { TGNFa receptors, EPHA2 }\end{array}$ \\
\hline CLN12 & Unknown & $\begin{array}{l}\text { ATPase 13A2, } \\
\text { KRPPD, PARK9, } \\
\text { HSA9947, RP- }\end{array}$ & $\begin{array}{l}10 \text { TM protein, } \\
1180 \text { aa }\end{array}$ & None & $\begin{array}{l}\text { Lysosomal } \\
\text { membrane }\end{array}$ & $\begin{array}{l}\text { Unknown / predicted } \\
\text { regulation of ion } \\
\text { homeostasis }\end{array}$ & $\begin{array}{l}\sim 43 \text { vesicular trafficking } \\
\text { and synuclein misfolding } \\
\text { postulated proteins }\end{array}$ \\
\hline
\end{tabular}


Table 1 Neuronal Ceroid Lipofuscinoses (Batten Disease) (Continued)

\begin{tabular}{|c|c|c|c|c|c|c|c|}
\hline $\begin{array}{l}\text { Mutant } \\
\text { Gene }\end{array}$ & $\begin{array}{l}\mathrm{NCL} \\
\text { Disease }\end{array}$ & $\begin{array}{l}\text { Encoded } \\
\text { Protein }\end{array}$ & $\begin{array}{l}\text { Classification } \\
\text { and protein } \\
\text { size }\end{array}$ & $\begin{array}{l}\text { Posttranslational } \\
\text { modification }\end{array}$ & $\begin{array}{l}\text { Subcellular } \\
\text { localization }\end{array}$ & Function & Interactions \\
\hline CLN13 & Unknown & $\begin{array}{l}\text { Cathepsin F } \\
\text { (CTSF) }\end{array}$ & $\begin{array}{l}\text { soluble protein, } \\
484 \text { aa }\end{array}$ & $\begin{array}{l}\text { N-gly } \\
\text { M6P }\end{array}$ & $\begin{array}{l}\text { Lysosomal } \\
\text { lumen }\end{array}$ & $\begin{array}{l}\text { Unknown / predicted: } \\
\text { cysteine protease }\end{array}$ & CD47 antigen \\
\hline CLN14 & Unknown & $\begin{array}{l}\text { Potassium } \\
\text { channel } \\
\text { tetramerization } \\
\text { domain- } \\
\text { containing } \\
\text { protein } 7 \\
\text { (KCTD7) }\end{array}$ & $\begin{array}{l}\text { soluble protein, } \\
289 \text { aa }\end{array}$ & Phosphorylated & $\begin{array}{l}\text { Cytosolic, } \\
\text { partially } \\
\text { associated to } \\
\text { membranes }\end{array}$ & $\begin{array}{l}\text { Unknown / predicted } \\
\text { modulation of ion } \\
\text { channel activity }\end{array}$ & Cullin-3, KCTD \\
\hline
\end{tabular}

Numerous studies have shown that both physiological and pathological conditions disrupt protein folding in the ER leading to the accumulation of these misfolded proteins, which cause ER-stress [69]. Increased ER stress activates a signaling network known as the unfolded protein response (UPR) to suppress protein synthesis [69]. In a wide variety of pathological conditions, including GM1 glycosidosis [70] and INCL [71], high levels of ER-stress have been reported to cause neuron loss. In response to ER stress, the protein-folding and degradation capacity of the ER is dynamically adjusted by the induction of the UPR [69]. Several comprehensive reviews have been published describing the prevalence of the UPR in the nervous system and its functional link in neurodegeneration [69, 71]. In $\mathrm{Cln}^{-1-}$ mice, ER- and oxidative-stress have been shown to cause caspase activation leading to neuron loss by apoptosis [72-74]. Recently, a comprehensive review on ER-stress and UPR in various LSDs including the NCLs has been published [75].

\section{CLN2/TPP1}

Mutations of the CLN2 gene encoding tripeptidylpeptidase 1 (TPP1) underlie pathogenesis of late infantile NCL (LINCL) or CLN2-disease [76]. TPP1 is a lysosomal protease that requires acidic $\mathrm{pH}$ for its activation. Moreover, inactivation of the aminopeptidase activity of TPP1 impairs the removal of tripeptides from the $\mathrm{N}$-terminus of small proteins leading to CLN2-disease [77, 78]. Children with LINCL are phenotypically normal at birth but around 2-4 years of age the disease manifestation occurs, and they succumb to the disease when they are around 6-15 years old.

Like cathepsin D (CTSD), a lysosomal aspartyl protease, TPP1 is synthesized as an inactive proenzyme (pro-TPP1) in the ER. It is then autocatalytically processed to the active enzyme in the acidic $\mathrm{pH}$ of the lysosome requiring $\mathrm{Ca}^{++}[79,80]$. The CLN2 gene is ubiquitously expressed and developmentally regulated [81]. In the human brain, TPP1 is expressed at a high level starting at 2 years of age [81] and in mice and rats, the highest expression level is reached at adulthood
[82]. Like most of the NCLs, the management of the patients with CLN2-disease is palliative. It requires a multidisciplinary approach as the disease has a complex array of symptoms and its progression is generally rapid. Moreover, because of the rapid decline of the medical condition of these patients, it is essential that the patient families are given extensive psychosocial support. An excellent review article has recently been published in which the authors provided a detailed overview of CLN2 disease and the associated complications that might be expected [83].

In both CLN2- and CLN3-diseases, endosomal/lysosomal trafficking as well as autophagy are reported to be dysregulated [84]. These abnormalities in CLN2deficient cells may stem from oxidative-stress, which upregulates the PI3/Akt pathway activating the mechanistic (mammalian) target of rapamycin complex 1 (mTORC1) [85]. Using induced pluripotent stem cells (iPSCs) from normal subjects and CLN2 patients, it has been shown that the earliest CLN2 disease events can be recapitulated in the human iPSCs at the pluripotent stage and during neuronal differentiation [86]. Moreover, these authors have reported distinct, yet overlapping, early-stage pathology in multiple subcellular compartments. Furthermore, the results of this study provided the proof-of-principle that establishes a platform for the development of genotype-directed therapeutics for NCL by drug screening in patient neurons differentiated from iPSCs. Remarkably, when the iPSCs were differentiated to neurons, other abnormalities characteristic of the CLN2-disease began to appear [86]. Notably, while LSD features were not detectable in iPSCs, disease-specific storage materials were seen upon neural differentiation of the same cells. Recently, an unbiased exhaustive proteomic analysis of the brain and cerebrospinal fluid from patients with CLN1-, CLN2- and CLN3-disease have revealed significant alterations in the expression of proteins in each of these NCLs [87]. Studies like these are likely to identify biomarkers for these diseases, which are essential for evaluating emerging therapeutic strategies and to determine their efficacy. 
Table 2 Mutant CLN genes and underlying pathophysiology of various forms of NCLs

\begin{tabular}{|c|c|c|c|c|c|c|c|}
\hline $\begin{array}{l}\text { Mutant } \\
\text { Gene }\end{array}$ & Cells/ tissues & $\begin{array}{l}\text { Myoclonus } \\
\text { \& Seizures }\end{array}$ & $\begin{array}{l}\text { Autofluorescent } \\
\text { inclusions }\end{array}$ & $\begin{array}{l}\text { Elevated } \\
\text { lysosomal } \\
\mathrm{pH}\end{array}$ & $\begin{array}{l}\text { ER } \\
\text { Stress }\end{array}$ & $\begin{array}{l}\text { Dysregulated } \\
\text { degradation }\end{array}$ & Cellular dysfunction \\
\hline CLN1 & $\begin{array}{l}\text { Ubiquitously expressed, CNS, } \\
\text { brain }\end{array}$ & $x$ & $x$ & $x$ & $x$ & $x$ & protein response \\
\hline CLN2 & $\begin{array}{l}\text { Ubiquitously expressed, brain, } \\
\text { neurons, cerebrospinal fluid }\end{array}$ & $x$ & $x$ & & & $x$ & Endocytic pathway dysfunction \\
\hline CLN3 & $\begin{array}{l}\text { Ubiquitously expressed, CNS, } \\
\text { immune and circulatory } \\
\text { systems, iPSC, neural progenitor } \\
\text { cells, colorectal cancer cells }\end{array}$ & $x$ & $x$ & $x$ & $x$ & $x$ & $\begin{array}{l}\text { TGN is impaired, localized on the } \\
\text { lysosome, cellular proliferation, } \\
\text { apoptosis and synaptic transmission }\end{array}$ \\
\hline CLN4 & $\begin{array}{l}\text { Ubiquitously expressed, } \\
\text { neuronal synapses ( } 1 \% \text { of total } \\
\text { synaptic vesicle-associated } \\
\text { proteins) }\end{array}$ & X (Type A) & $x$ & $x$ & - & - & $\begin{array}{l}\text { Type: B manifests movement } \\
\text { abnormalities with dementia }\end{array}$ \\
\hline CLN5 & $\begin{array}{l}\text { Ubiquitously expressed in } \\
\text { human tissue, CNS, peripheral } \\
\text { organs and tissues, neurons } \\
\text { (ganglionic eminence) and } \\
\text { microglia }\end{array}$ & $x$ & $x$ & $x$ & & & $\begin{array}{l}\text { Endosomal sorting, the stability of } \\
\text { sortilin and CIMPR both declines, } \\
\text { defective myelination }\end{array}$ \\
\hline CLN6 & Ubiquitously expressed & $x$ & $x$ & & $x$ & $x$ & $\begin{array}{l}\text { manifest characteristic cholesterol and } \\
\text { subunit c of mitochondrial ATP } \\
\text { synthase (SCMAS), aberrant biometal } \\
\text { metabolism }\end{array}$ \\
\hline CLN7 & $\begin{array}{l}\text { Ubiquitously expressed at a } \\
\text { very low level, its expression in } \\
\text { the liver, heart, and pancreas } \\
\text { (markedly higher) }\end{array}$ & $x$ & $x$ & $x$ & & $x$ & $\begin{array}{l}\text { loss of CLN7 causes depletion of } \\
\text { soluble proteins in the lysosomes } \\
\text { impairing reactivation of mTOR }\end{array}$ \\
\hline CLN8 & $\begin{array}{l}\text { Ubiquitously expressed, high } \\
\text { level expression in cerebral } \\
\text { cortex and hippocampus in } \\
\text { electrical kindling model of } \\
\text { epilepsy }\end{array}$ & $x$ & $x$ & & $x$ & $x$ & $\begin{array}{l}\text { progressive motor neuron dysfunction } \\
\text { and retinal degeneration, lysosomal } \beta \text { - } \\
\text { glucosidase deficiency, }\end{array}$ \\
\hline CLN9 & Currently designated as CLN4 & - & - & - & - & - & \\
\hline CLN10 & Ubiquitously expressed, brain & $x$ & $x$ & $x$ & & $x$ & CTSD-processing \\
\hline CLN11 & $\begin{array}{l}\text { Ubiquitously expressed, CNS, } \\
\text { neuron, microglia, astrocytes, } \\
\text { and endothelial cells }\end{array}$ & $x$ & $x$ & $x$ & - & - & $\begin{array}{l}\text { significantly activated microglia after } \\
\mathrm{TBI} \text {, the elevated lysosomal biogenesis } \\
\text { in activated microglia, which increased } \\
\text { cerebrocortical neuron damage, } \\
\text { reduces lysosomal biogenesis }\end{array}$ \\
\hline CLN12 & $\begin{array}{l}\text { Ubiquitously expressed, ventral } \\
\text { midbrain, including substantia } \\
\text { nigra (high lever), kidney and } \\
\text { skeletal muscle (low level) }\end{array}$ & $x$ & $x$ & $x$ & - & - & $\begin{array}{l}\text { extrapyramidal involvement, oxidative- } \\
\text { stress in neuroblastoma cells; } \\
\text { dysregulated neurotransmission }\end{array}$ \\
\hline CLN13 & $\begin{array}{l}\text { CTSF is expressed at a high } \\
\text { level in cerebrocortical, } \\
\text { hippocampal and cerebellar } \\
\text { neurons }\end{array}$ & $x$ & $x$ & $x$ & - & - & $\begin{array}{l}\text { neurons showed accumulation of } \\
\text { eosinophilic granules }\end{array}$ \\
\hline CLN14 & $\begin{array}{l}\text { Ubiquitously expressed, } \\
\text { cerebrocortical and cerebellar } \\
\text { Purkinje cells, pyramidal cell } \\
\text { layers of the hippocampus } \\
\text { (high levels) }\end{array}$ & $x$ & $x$ & $x$ & - & - & disrupt KCTD7-Cullin-3 interactions \\
\hline
\end{tabular}

\section{CLN3/ Batten disease}

The CLN3 gene was identified in 1995 and it was reported that mutations in this gene underlie juvenile NCL (JNCL) [88]. It encodes a 438-amino acid transmembrane lysosomal protein with both its $\mathrm{N}$ - and C-termini localized to the cytoplasm
$[89,90]$. The CLN3 mutations as well as clinicopathological spectrums have previously been reviewed [91].

The most frequent disease-causing mutations in this gene, found in patients with CLN3-disease, is a $1 \mathrm{~kb}$ deletion that causes removal of exons 7 and 8 , which 


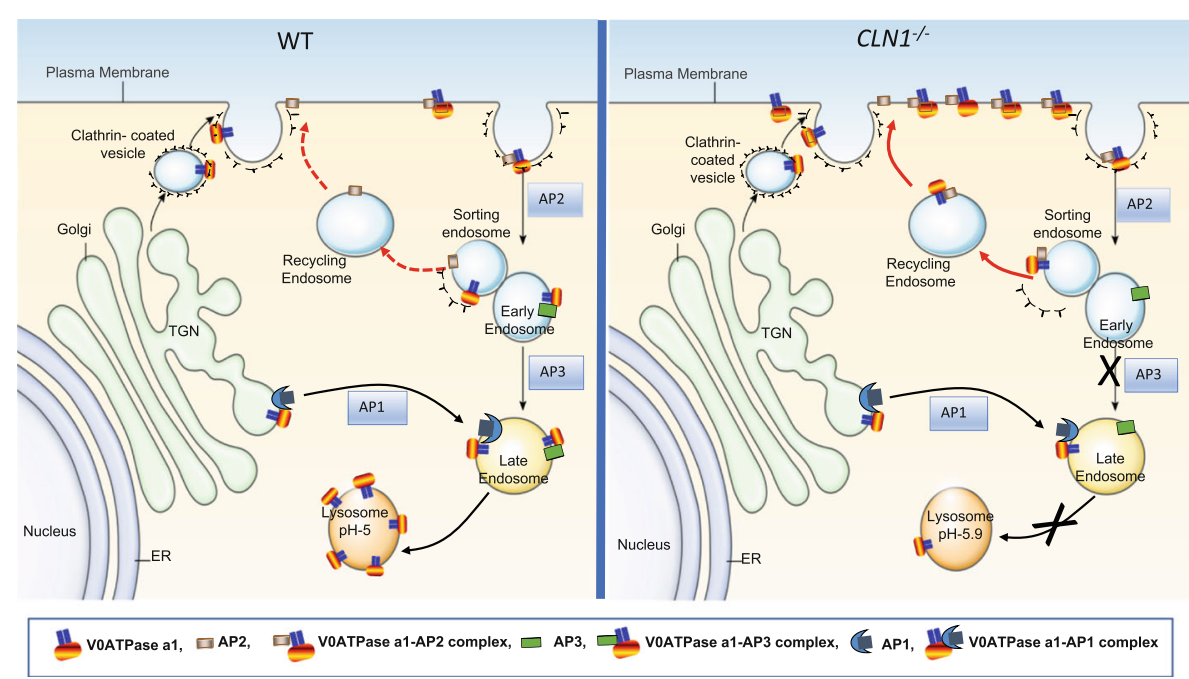

Fig. 2 Dysregulation of lysosomal acidification in a mouse model of infantile NCL. Schematic representation of endosomal sorting and trafficking of a critical subunit of $\mathrm{V}$-ATPase, the proton pump that maintains acidic $\mathrm{pH}$ of the lysosomal lumen. We recently uncovered that V0a1 requires S-palmitoylation for its endosomal transport to the lysosomal membrane (see ref. [67]). In Cln ${ }^{\%}$ mice (right panel), the lack Ppt1 causes misrouting of $\mathrm{VO}$ a1 to the plasma membrane instead of its normal location on the lysosomal membrane as seen in WT mice (left panel). Note that in $\mathrm{Cln}^{-1-}$ mice, Ppt1-deficiency impairs the dissociation of V0a1 from AP-2, preventing its interaction with AP-3, which is essential for its transport from the sorting endosome to the late endosomal/lysosomal membrane. Consequently, the V0a1-AP-2 complex is misrouted to the plasma membrane via recycling endosome. This defect impairs v-ATPase activity, thereby dysregulating lysosomal acidification in neurons and other cells in $\mathrm{Cln}^{-1-}$ mice. Since lysosomal hydrolases require acid $\mathrm{pH}$ for optimal catalytic activity, we propose that elevated lysosomal pH contributes to neuropathology in $\mathrm{Cln} 1^{-1-}$ mice and most likely in INCL patients

generates a premature stop codon [88]. This mutation results in a substantial decrease in mRNA expression and stability. Therefore, it is likely that the mutant gene expressing a truncated CLN3-protein is not expressed at all [92]. In both humans and mice, the $C L N 3 / C \ln 3$-gene and $C L N 3 / C \ln 3$-protein are ubiquitously expressed [93]. It has been reported that mutations in the CLN3 gene impair loss of vision, cause epileptic seizures, as well as progressive decline in motor and cognitive functions. However, there are reports providing evidence that CLN3-pathology also extends beyond the central nervous system for example, the immune- and circulatory systems [94-96]. Although lysosomal localization of CLN3 has also been reported, it is also localized to the neuronal synapses and growth cones of telencephalic neurons of mice. Furthermore, CLN3 has been shown to colocalize with the SV proteins such as SV2 and synaptophysin [97-99]. Thus, it has been suggested that CLN3 may have a role in endosomal/lysosomal system as well as in neuronal synapses.

While the precise function of CLN3 is not yet clearly understood, its localization primarily on late endosome and lysosome is suggestive of its important roles in these organelles [99, 100]. Notably, in CLN3-ablated HeLa cells expressing CD8-tagged CI-M6PR as the reporter, it has been demonstrated that in these cells the exit of CD8-CI-MPR from the TGN is impaired [101]. Recent reports indicate that CLN3 plays a critical role in autophagy and this process is defective in CLN3-disease models [102]. Moreover, using juvenile CLN3 disease patient-derived iPSCs and neural progenitor cells derived from juvenile CLN3 disease it has been shown that autophagy is defective [103]. In addition to its localization on the lysosomal membrane and its role in the function of this organelle, CLN3-silencing has been shown to stimulate proliferation in human colorectal cancer cells [104]. Interestingly, it is reported that the wild, but not the mutant CLN3, binds galactosylceramide suggesting that it may transport galactosylceramide [105]. Moreover, it has also been demonstrated that suppression of galactosylceramide synthase by siRNA in normal cells adversely affected cellular growth and induced apoptosis. Notably, storage of subunit c of ATP synthase has also been reported in all NCLs except in INCL. However, it has been reported that the accumulation of subunit $c$ does not cause the neuropathology characteristic of NCL-diseases [106]. Considering all these observations, it appears that CLN3 mutation adversely affects several cellular processes such as lysosomal $\mathrm{pH}$, endocytosis, autophagy, transport of proteins from the TGN, cell proliferation, apoptosis and synaptic transmission, although it remains unclear what precise biological function(s) CLN3 regulates and what is the mechanism of such regulation. Recently, using human iPSC models of NCLs Lojewski and colleagues [86] have reported 
endocytic pathway dysfunction in cells carrying mutations in the CLN2- and CLN3-genes, respectively. Although phosphorylation of TFEB, which prevents its translocation to the nucleus, is catalyzed by mTORC1, it has recently been reported that in a CLN3 disease model, TFEB activation has been achieved by the inhibition of Akt by trehalose, which mediated cellular clearance and neuroprotection [107].

\section{CLN4 / DNAJC5}

Mutations in the CLN4 / DNAJC5 gene encoding CSP $\alpha$ underlie the adult onset form of NCL also called Parry disease [108], is a very rare and difficult to diagnose NCL [106]. At least two variants of Kufs disease have been reported [109]. The type A variant is a progressive myoclonus epilepsy with cognitive impairment, and type $B$ variant manifests movement abnormalities with dementia [110-112]. Although most of the NCLs are autosomal recessive diseases, the inheritance pattern of type A Kufs disease (CLN6 mutations) is autosomal dominant [112]. Proper folding of proteins plays critical roles in their function and it has been reported that CSP $\alpha$ acts as a chaperone to facilitate correct folding of proteins [113]. Thus, its localization in the neuronal synapses accounts for $1 \%$ of total synaptic vesicle-associated proteins. In the neuronal synapses, $\alpha$-synuclein ( $\alpha$-Syn) and CSP $\alpha$ are present in abundance [114]. Although it has been reported that dominant mutations in $\alpha-S Y N$ gene cause Parkinson's disease, the physiological role(s) of $\alpha$-Syn remains elusive. Targeted-disruption of the CSP $\alpha$ gene results in progressive neurodegeneration in mice and it has been suggested the co-chaperone function of CSP $\alpha$ is required for the survival of neurons [115]. Remarkably, it has been found that transgenic expression of $\alpha$-Syn prevents neurodegeneration caused by CSP $\alpha$-ablation. These results demonstrate not only the neuroprotective role of $\alpha$-Syn, but also how CSP $\alpha$ works in concert with $\alpha$-Syn in the nerve terminals to protect the neurons [115]. Interestingly, a recent study has reported that DNAJC5/CSP $\alpha$ and PPT1/CLN1, which is mutated INCL, may be functionally linked [67].

\section{CLN5}

The CLN5 gene encodes a soluble lysosomal glycoprotein of unknown function. Although its mutations were first discovered in the Finish variant of late infantile NCL, they are now reported in both juvenile and adult NCL patients of a wide range of ethnicities $[116,117]$. CLN5's expression varies throughout the body, having the highest levels in the central nervous system and moderate levels in the peripheral organs and tissues. In the brain, it is highly expressed in the cerebral cortex and cerebellum [118]. Similar expression patterns occur in the mouse brain where it is also developmentally regulated. Moreover, it is expressed in the ganglionic eminence and microglia, the latter of which sees very early activation in $C \ln 5^{-1-}$ mice, which may adversely affect adjoining normal neurons. In addition, CLN5-protein has been reported to localize to the lysosomal compartment [119] and CLN5 overexpression in COS-1 cells has been shown to interact with CLN1/PPT1, CLN3, CLN6, CLN8, and endogenous CLN2/TPP1 [120].

Although the precise function of CLN5 encoded protein remains unclear, it has been reported that it plays a role in endosomal sorting [121]. Indeed, it has been shown that in HeLa cells, overexpressing HA-tagged CLN5 and myc-tagged sortilin, a lysosomal enzyme transporter, both are coimmunoprecipitated. This suggested an interaction between these two proteins. Conversely, in CLN5-deficient cells the stability of sortilin and CIMPR both declined [122]. The importance of CLN5 in the brain is suggested by its relatively high expression in neurons and microglia [118]. Moreover, patients with late infantile CLN5-disease and in the brains of $\mathrm{Cln} 5^{-1}$ mice, defective myelination occurs in the brain [118]. Further investigations are likely to delineate the precise physiological function(s) of the CLN5 gene product.

\section{CLN6}

Mutations in the CLN6 gene cause classical and variant late infantile NCL $[123,124]$. CLN6 encodes a $27 \mathrm{kDa}$ transmembrane ER-protein of 311 amino acids, which is expressed in virtually all tissues, including the cerebellum and the hypothalamus. However, its biological function(s) remain obscure and there is currently no known protein homologue of CLN6 [125]. The expression of $\mathrm{Cln} 6$ is developmentally regulated in the murine brain and mice aged P14 and older express Cln6-mRNA in cells of the cerebral cortex (layers II-VI), cerebellar Purkinje cells and in the dentate gyrus of the hippocampus. Moreover, it has been reported that CLN6 has a role in the regulation of cellular acidification, endocytosis and autophagy [126-128]. CLN6 mutations also manifest characteristic NCL phenotypes in lysosomal storage granules such as intracellular autofluorescent lipopigments (constituent of ceroid), cholesterol and subunit c of mitochondrial ATP synthase (SCMAS) [106, 126]. However, SCMAS are absent in lipopigments of CLN1, CLN4 and CLN10. It remains unclear if SCMAS are present in the lipopigments in CLN11-CLN14. Notably, it has been reported that there is no difference in the total mannose 6-phosphate proteome in brain tissues from patients with CLN6-disease and healthy controls [129]. One of the striking findings in CLN6-disease is the aberrant biometal metabolism, which is also reported in common neurodegenerative disorders such as Parkinson's 
and Alzheimer's [130]. Biometals such as copper, zinc, manganese and cobalt have been shown to accumulate in animal models of CLN6 disease [130]. In Cln6 mutant (nclf) mice, accumulation of these biometals has been reported in the cerebral cortex, spinal cord, liver and heart [131]. Further investigations are required to determine the biological function(s) of CLN6 and how impaired function of this gene leads to the accumulation of biometals and how this defect leads to CLN6 disease pathogenesis.

\section{CLN7}

Mutations in the MFSD8 gene cause CLN7-disease, which is a variant late infantile phenotype [132]. Although MFSD8 is ubiquitously expressed at a very low level, its expression in the liver, heart and pancreas is markedly higher. Interestingly, rat neurons, astrocytes and microglia as well as cultured microglial cells showed much higher levels of $M f s d 8$-mRNA [133]. The abundance of $M f_{s} d 8$-mRNA was more pronounced in the cerebral cortex and the midbrain and much less pronounced in the hippocampus [133]. MFSD8 is a multispan integral lysosomal membrane protein belonging to the major facilitator superfamily (MFS) of active permeases. These proteins function as transporters of sugars, sugar phosphates, drugs, inorganic and organic cations, amino acids and neurotransmitters across membranes. However, its precise biological function remains unclear. Results from colocalization studies of MFSD8 and lysosomal membrane markers suggest lysosomal localization of this protein [134]. Studies using lysotracker red and Lamp-1 colocalization in HeLa cells with GFP-tagged MFSD8 found similar results [135]. Remarkably, none of the pathogenic MFSD8 mutations had any adverse effect on protein trafficking or lysosomal localization [133]. It has been reported that in $C \ln 7-\mathrm{KO}$ mice, loss of $C \ln 7$ in the brain leads to lysosomal dysfunction and impairs constitutive autophagy leading to neurodegeneration late in the disease process [136]. It has also been demonstrated that CLN7-protein is cleaved by lysosomal proteinases generating $\mathrm{N}$ - and $\mathrm{C}$-terminal fragments, which are then released in the extracellular space. Loss of CLN7 causes depletion of soluble proteins in lysosomes impairing reactivation of mTOR [137], which is a potent anabolic regulator of cell growth and metabolism. Further investigations are essential to delineate the specific role(s) of CLN7 in neurons and how MFSD8 mutations may lead to CLN7 disease.

\section{CLN8}

In humans, CLN8 mutations manifest two distinct phenotypes. One of these phenotypes is characterized by progressive seizures and mental retardation and the other is a juvenile-onset variant, which is called Northern Epilepsy [138]. The CLN8 gene encodes an ER membrane-spanning protein containing several hydrophobic domains. The protein is reported to shuttle between the ER and Golgi intermediate compartment for recycling. In non-neuronal cells, CLN8 contains an ER-retrieval signal KKRP (Lys-Lys-Arg-Pro) at the carboxy terminal $[139,140]$. The naturally occurring mouse model of the disease called mnd (motor neuron degeneration) shows progressive motor neuron dysfunction and retinal degeneration [140]. CLN8-mRNA is expressed ubiquitously with high level expression in cerebral cortex and hippocampus in electrical kindling model of epilepsy [141]. However, the relevance of CLN8 overexpression in this model still needs to be determined. Although the precise function of CLN8 remains unclear, a 200-amino acid (residues 62-262) TLC (TRAMLAG1-CLN8) domain has been suggested to be essential for ceramide synthesis, glycosphingolipid trafficking [140] and lipid homeostasis [142, 143]. Of note, a report suggested $C L N 8$ as a genetic modifier after the stimulation of CLN8-mRNA expression in a chemically induced Gaucher disease model [144]. However, the mechanism by which CLN8 expression is induced in this model, which is caused by lysosomal $\beta$-glucosidase deficiency, remains unclear. Interestingly, several studies suggested that altered CLN8 function may be linked to ER- and oxidative-stresses (reviewed in [75]), disruption of calcium homeostasis, defective mitochondrial function, inflammation and apoptosis [145-147]. A recent study demonstrates that CLN8 protein is retrieved from the Golgi complex to the ER via coat-protein I (COPI) and that mutations in the CLN8 gene impairs the transport of lysosomal enzymes such as TPP1 leading to pathogenesis of CLN8-disease [148]. Undoubtedly, further research is needed to understand the mechanism(s) of pathogenesis of CLN8-disease.

\section{CLN9/reclassified as CLN4 CLN10/ CTSD}

Mutations in the CLN10 gene cause a severe neurodegenerative LSD called congenital NCL (CNCL) [149, 150]. Clinically, congenital NCL (CLN10 disease) manifests with respiratory insufficiency after birth and status epilepticus, which are followed by death within hours to weeks ([149] and references there in). The CLN10 gene encodes cathepsin D (CTSD; EC 3.4.23.5), an aspartic protease belonging to the pepsin superfamily. It is associated with several physiological processes such as protein degradation, autophagy and apoptosis [151]. CTSD hydrolyzes a wide variety of substrates including the extracellular matrix proteins fibronectin and laminin. However, the in vivo substrates of this enzyme have not been clearly identified although it has been reported that CTSD catalyzes the cleavage of $\alpha$-synuclein [152], a protein associated with Parkinson's disease. 
Human subjects with CLN10-disease either die prenatally or within a few weeks after birth. Typically, these patients present with microcephaly and seizures and unlike other forms of NCLs they lack the progressive cognitive/motor or visual deficits [153, 154]. Sporadic mutations in the CLN10 gene causing CTSD deficiency in sheep have been reported as congenital ovine NCL [155] and in American bulldogs [156].

Mammalian CTSD is synthesized as a $53 \mathrm{kDa}$ pre-pro enzyme protein [157]. The pre-pro-CTSD is first proteolytically processed to a $48 \mathrm{kDa}$ proenzyme, which then is transported through the endosomal pathway to the lysosome. Here the proenzyme is further processed by the proteolytic actions of cathepsin $\mathrm{B}$ and $\mathrm{L}$, generating a $31 \mathrm{kDa}$ and a $14 \mathrm{kDa}$ fragment; non-covalent dimerization of these two fragments constitutes the mature, catalytically active-CTSD enzyme [157]. Variable $\mathrm{pH}$ optima have been reported for CTSD but maximal enzymatic activity is manifested at a pH optimum of 3.5 (26). Purified CTSD from porcine spleen has shown a $\mathrm{pH}$ optimum near 3 and 4, which has been reported to vary with salt concentration [158].

Several animal models with inactivating mutations in the CLN10/CTSD gene manifest CNCL phenotype. Targeted-disruption of the $C \ln 10 / C t s d$ gene has been reported to cause an early-onset NCL phenotype and progressive neurodegeneration in mice and Drosophila [159-162]. It has also been reported that CTSDprocessing is defective in lysosomes derived from the brain of $C \ln 1^{-/-}$mice, which suggests that lysosomal deficiency of enzymatically active CTSD is a common pathogenic link between INCL and CNCL [163].

\section{CLN11/PGRN}

The CLN11 gene encodes progranulin (PGRN). In 2012, mutations in the PGRN gene were first reported in two siblings suffering from an adult-onset NCL [164]. PRGN was originally described as a growth factor that regulates wound healing, vasculogenesis and tumor growth [165]. However, in 2006, landmark studies showed that mutations in the GRN gene also underlie a familial form of frontotemporal lobar degeneration (FTLD) with distinct neuropathological features consisting of ubiquitin-positive protein aggregates in the nucleus and cytoplasm of cortical neurons [166]. Subsequently, these aggregates were found to be enriched in TAR DNA-binding protein-43 (TDP43) [167]. Moreover, it was discovered that patients with homozygous GRN mutations developed NCL-11 $[164,168]$. Interestingly, while heterozygous mutations in the granulin gene $(G R N)$ in older adults lead to haploinsufficiency in PGRN, which causes FTLD, homozygous mutations in the GRN gene lead to complete PGRN loss, which causes CLN11-disease in children [169]. However, the cause of the differential pathologic manifestation remains unclear.

Within the central nervous system GRN-mRNA is expressed in a variety of cell types including neuron, microglia, astrocytes and endothelial cells [170]. Despite its potential role in lysosomal function, the presence of a secretory signal in the N-terminal of GRN protein facilitates its regulated secretion [171]. Interestingly, microglial activation enhances progranulin expression and significantly impacts neuronal function and synaptic density [172]. Extracellular progranulin can bind to multiple receptors including sortilin, which transports it to the lysosome [173]. Progranulin also binds to TNF $\alpha$-receptor [174] as well as the ephrin type-A receptor (EPHA2) on the cell surface and such interactions activate tyrosine kinase activity of EPHA2 and downstream kinase Akt [175]. This may suggest that signaling pathways downstream of Akt may also be activated by progranulin.

Although PGRN has been shown to be transported to the lysosome via sortilin [176], its function(s) in this organelle remains unclear. In macrophages, granulins, cleaved from PGRN, bind to CpG oligodeoynucleotides in lysosomes, enabling Toll-like receptor-9 signaling [177]. Recently, it has been reported that in the mouse traumatic brain injury model, PGRN prevents lysosomal dysfunction [178]. Most notably, the expression of PGRN is significantly elevated in activated microglia after traumatic brain injury. The elevated lysosomal biogenesis in activated microglia, which increased cerebrocortical neuron damage, reduces lysosomal biogenesis [54, 179]. It has been reported that PGRN-deficiency causing lysosomal dysfunction can be explained based on lipidomic and transcriptomic considerations [180]. In a recent comprehensive review, Paushter and colleagues have provided new insights into the lysosomal function of PGRN and its link to multiple neurodegenerative diseases [181]. More research would be needed to advance our understanding of the role of PGRN in the pathogenesis of CLN11- and FTD-diseases.

\section{CLN12/ATP13A2}

The CLN12 disease is caused by loss of function mutations in the predominantly neuronal P-type ATPase (ATP13A2) gene. The CLN12 (ATP13A2) gene is also known as KRPPD, PARK9, HSA9947, RP-37C10.4. It encodes a $36 \mathrm{kDa}$ lysosomal transmembrane protein containing 10 predicted transmembrane domains [182], which were previously shown to underlie a rare form of autosomal recessive juvenile-onset Parkinson dementia called Kufor-Rakeb syndrome [183]. The patients afflicted with this syndrome manifest characteristics of not only typical NCL, but also show extrapyramidal involvement. Postmortem pathological examination of the brain tissues from a Kufor-Rakeb syndrome patient with 
homozygous missense mutations in the ATP13A2 gene showed extensive deposition of lipofuscin in the retina, cerebral cortex, basal ganglia and cerebellum [183]. In most human tissues, CLN12-mRNA is detectable, but it is expressed at a high level in the ventral midbrain, including substantia nigra, and to a lesser extent in the kidney and skeletal muscle [182].

CLN12/ATP13A2 gene product is targeted to the acidic compartments of the cell including the late endosome and lysosome [182, 183]. Cultured fibroblasts derived from patients with Kufor-Rakeb syndrome as well as ATP13A2-deficient cell lines have demonstrated that loss of this protein impairs lysosomal acidification, which in turn impairs the degradation of cargo by lysosomal hydrolases disrupting lysosome-mediated clearance of the autophagosomes [182, 184]. Recently, it has been uncovered that impaired CLN12/ATP13A2 function causes oxidative-stress in human neuroblastoma cells [185]. Interestingly, oxidative-stress is found to increase the expression of the CLN12/ATP13A2-mRNA [186]. A comprehensive review on this subject has been published linking its role as a cation transporter regulating $\mathrm{Mn}^{2}+, \mathrm{Zn}^{2}+\mathrm{Mg}^{2}+$ homeostasis with $\mathrm{H}^{+}$ions concentration in the cell [187]. A pathogenic link has been suggested between CLN12/ATP13A2 and Parkinsonism as they both protect neurons against $\alpha$-Syn toxicity. Since cation regulation and homeostasis are vital for neuronal function including intra- and inter-cellular signaling [188], the loss of transporter function of the ATP13A2 may explain the dysregulated neurotransmission and eventual dementia characteristic of CLN12 disease.

\section{CLN13/CTSF}

The CLN13 gene encodes cathepsin F (CTSF) and mutations in this gene were originally reported in mice [189], which develop neurological disease with accumulation of autofluorescent material in neurons of the cerebral cortex, hypothalamus, cerebellar Purkinje cells and other regions of the brain. The neurological disease develops between 12-16 months of age and is characterized by the lack of coordination, muscular weakness and premature death. The pathological findings in the brain also include numerous activated microglial cells [189]. Recently, 3 families with adult-onset NCL causing dementia and motor disturbances without epilepsy have been described [190, 191]. These patients carried rare mutations in the CTSF gene, which were identified after linkage analyses, and exome sequencing. CTSF is a cysteine protease consisting of 484 amino acids. It contains a 251-amino acid pro-peptide consisting of a N-terminal cystatin-like pro-region, which works as a cysteine protease inhibitor [192]. Synthesized in the ER, CTSF is tagged with mannose 6-phosphate residues in the cis-Golgi and transported by CI-M6PR to the late endosomal/lysosomal compartment [193]. CTSF is expressed at a high level in cerebrocortical, hippocampal and cerebellar neurons [190]. Although CTSF is recognized as a lysosomal cysteine proteinase, its in vivo function remains obscure. Targeted-disruption of the CTSF gene in mice has been carried out and phenotypic characterization of the $\mathrm{CTSF}^{-1}$ animals shows that they are apparently healthy and reproduced normally. However, these mice manifested progressive weakness in their hind legs and declining motor coordination at 12 to 16 months of age. This was followed by significant weight loss leading to death. Pathologic analysis of the CTSF-deficient neurons showed accumulation of eosinophilic granules that had characteristics of lysosomal lipofuscin as well as elevated levels of autofluorescent lipofuscin, which are characteristic of all NCLs. These findings may indicate that CTSF either only mildly affects the phenotype or is mildly compensated by other gene product(s). Thus, the phenotypic manifestation of CTSF-deficiency requires a longer period for the manifestation of CLN13-disease symptoms [190].

\section{CLN14}

Progressive myoclonic epilepsy (PME) is a clinically defined epileptic syndrome that manifests as myoclonic seizures and progressive neurological dysfunction [194, 195]. Mutations in the potassium channel tetramerization domain-containing protein 7 (KCTD7) have been extensively linked to progressive myoclonic epilepsy [196]. Moreover, homozygous mutations in the KCTD7 gene have been reported to cause a subtype of NCL discovered in two siblings in a Mexican family who presented with infantile-onset, progressive myoclonic epilepsy, cognitive impairment, loss of vision, motor regression, and premature death. Pathological analysis showed prominent NCL-type storage material [197]. Further analyses showed that these patients carried a missense mutation in the KCTD7 gene and pathological analysis showed autofluorescent storage material characteristic of the NCLs. Currently, KCTD7 gene represents CLN14 [197].

KCTD7 is a member of the KCTD protein family [198]. It is a highly conserved protein consisting of 289 amino acids, and in the mouse, it is predominantly expressed in the cerebrocortical and cerebellar Purkinje cells as well as in the pyramidal cell layers of the hippocampus [197]. It is a soluble cytosolic protein. The structure and localization of KCTD7 in various organs suggests that it is involved in hyperpolarization of the cell membrane via interaction with a component of the ubiquitin ligase complex [198]. In a patch clamp study, it has been demonstrated that KCTD7 overexpression in murine neurons hyperpolarizes the cell membrane and decreases excitability of these cells. Moreover, KCTD7 directly interacts with Cullin-3, a component of E3 ubiquitin-protein ligases, for degradation by ubiquitin- 
proteasome system. Furthermore, missense mutations in the KCTD gene found in CLN14 disease, disrupt KCTD7-Cullin-3 interactions, which suggests that such mutations may impair cellular degradative process [197, 198].

\section{Emerging new roles of the lysosome in the context of NCLs}

How might emerging new roles of the lysosome clarify the differential pathologic manifestations in the NCLs? The lysosome has been known as the major degradative and recycling organelle in the cell. However, it is increasingly being recognized as a "command and control center for cellular metabolism" [199]. A clear understanding of the emerging new roles of the lysosome as a "regulatory Hub" [200] in the cell may clarify how mutations in 13 different CLN genes may impair lysosomal function. The endo-lysosomal pathway requires coordinated expression and action of various components that regulate the action(s) of the acid hydrolases, lysosomal acidification machinery, and the lysosomal membrane proteins. Recently, it has been reported that a motif (10 base pair sequence) near the transcription initiation site of many genes, designated as coordinated lysosomal expression and regulation (CLEAR), controls the expression of the genes that encode many lysosomal proteins [12]. The transcription factor EB (TFEB), upon translocation to the nucleus, binds to the CLEAR element and promotes the expression of many genes encoding lysosomal proteins [53]. Indeed, the CLEAR element is found in many genes encoding both non-lysosomal and lysosomal proteins including LAMP1, NPC1 and NPC2, $\beta$-galactosidase, CTSD, CLN3 and CLN5 [12]. However, TFs other than TFEB may also regulate the transcription of proteins such as progranulin, which is associated with neurodegenerative disorders like FTLD and neurodegenerative LSDs like CLN11 disease [180]. Notably, in the LSDs, the TFEB translocates from the cytoplasm to the nucleus activating its target genes. However, the phosphorylation of TFEB by mTORC1 prevents its translocation from the cytoplasm to the nucleus. These events attest to the fact that a genetic program regulates lysosomal biogenesis and function [201, 202]. It is noteworthy that the activation of mTORC1 impairs autophagy [199] and dysregulation of lysosomal acidification impairs autophagy in common neurodegenerative diseases like Alzheimer's [44, 203]. Moreover, mTORC1 activation has been reported in JNCL [84] and recently, it has been shown that TFEB activation by mTORC1-independent pathway can be stimulated by suppression of Akt by trehalose, which appears to be neuroprotective and lifespan expanding in a mouse model of CLN3-disease [106]. In virtually all LSDs including most of the NCLs lysosomal acidification is dysregulated [25, 26, 67]. Since dysregulation of autophagy has been suggested as a common mechanism underlying pathogenesis of the LSDs including the NCLs [16], suppression of mTORC1 activation is being considered as a therapeutic strategy for these diseases.

Within less than a decade, the discovery that the lysosome responds to environmental cues by sensing the nutritional status of the cell and regulating both cellular clearance and energy production has opened a new era in lysosomal research. It has been reported that activation of mTORC1 localized on the lysosomal membrane regulates cellular growth and homeostasis [204]. In this regulatory system, the nutrients in lysosomal lumen promote TFEB-phosphorylation catalyzed by mTORC1, which inhibits the activity of TFEB. Notably, inhibition of $\mathrm{mTORC1}$ by its inhibitors like rapamycin, activates TFEB by its translocation to the nucleus. Similar results were obtained when the cells were starved to deplete nutrients like amino acids in the lysosomal lumen. Interestingly, the Rag GTPases in coordination with the v-ATPase-Ragulator complex sense lysosomal amino acids activating mTORC1. Thus, the lysosome appears to sense its luminal content to regulate its own biogenesis by an "inside-out" signaling mechanism, which requires both TFEB and mTOR [54, 205]. Notably, S6K1 is phosphorylated by mTORC1 and in the brain of $\mathrm{Cln}^{-1-}$ mice elevated p-S6K1 levels have been reported [206] suggesting dysregulation of mTORC1, which may impair autophagy. The mTORC1 is a multiprotein complex, which together with the Rag GTPases, Ragulator, and the $\mathrm{v}$-ATPase, forms an amino acid-sensing machinery on lysosomal surface, which at multiple levels affects the decision between cell growth and catabolism [204]. Moreover, diminished mTORC1-dependent JNK activation in Drosophila has been shown to cause neurodevelopmental defect. An elegant review on the roles of mTOR activation in several neurodegenerative diseases has recently been published [205]. Although the mTORC1 signaling in NCL diseases has not been studied extensively, it has recently been reported that mutations in the CLN7 gene cause depletion of soluble lysosomal proteins, which impair mTOR reactivation [136]. It is likely that mTOR signaling abnormalities may underlie pathogenesis of other NCLs besides CLN7-disease.

Recently, it has been uncovered that in Ppt1-deficient $C \ln 1^{-1-}$ mice, the misrouting of V0a1 subunit of the lysosomal v-ATPase dysregulates lysosomal acidification [68]. Since v-ATPase on the lysosomal membrane is one of the components of the nutrient sensing machinery which regulates mTORC1 signaling [Fig. 3], it is possible that mTORC1 signaling is defective in all NCLs including the CLN1-disease. This is one area of investigation that may provide insight into the pathogenesis of INCL. Interestingly, dysregulated lysosomal $\mathrm{pH}$, which is also 


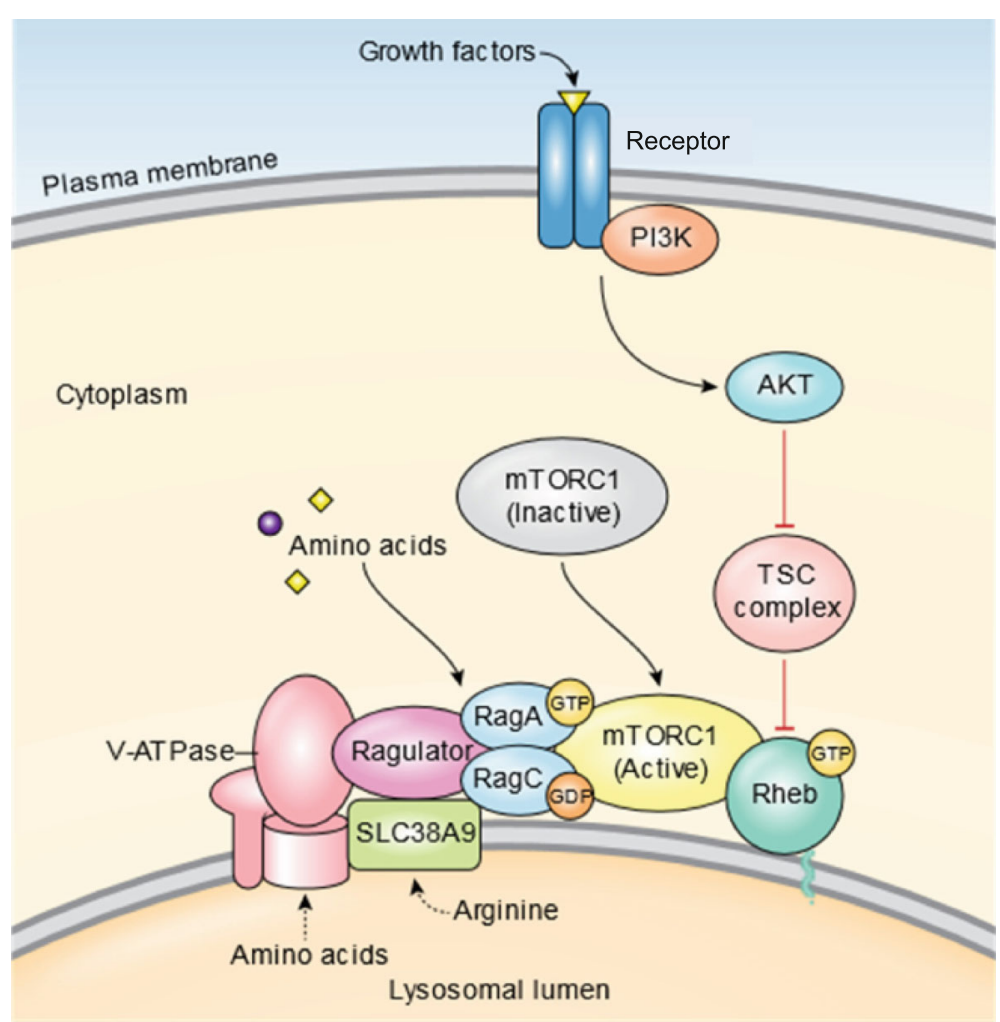

Fig. 3 Lysosome as the nutrient sensor and signaling hub of the cell. Emerging evidence indicates that the lysosome in addition to performing its digestive function also acts as a signaling hub for regulating cellular metabolism. In growing cells, signals from amino acids (e.g. arginine, leucine etc), within the lysosomal lumen are integrated upstream of the Rag and Rheb GTPases to promote recruitment of mTORC1 on lysosomal membrane leading to its activation. Signals from other factors such as oxygen and growth factors are also integrated in this fashion by the AKT-TSC pathway. Upon activation, AKT relieves the TSC complex from inhibiting Rheb. The v-ATPase, Ragulator, Rag GTPases and SLC38A9 also participate in the complex process of mTORC1-translocation to the lysosomal membrane where it is activated. Disruption of one or more of these signaling inputs may impair mTORC1 signaling and its recruitment to the lysosomal membrane suppressing its kinase activity. It should be noted that in a nutrient replete state the mTORC1 activation stimulates cell proliferation (anabolic effect), whereas in nutrient depleted state mTORC1 is inactive allowing autophagic pathway to be active (catabolic effect). Most notably, inhibition of mTORC1 by rapamycin and its analogs has been reported to ameliorate pathology and increase lifespan. Abbreviations used: mTORC1, mechanistic target of rapamycin complex 1; AKT, Protein kinase B; TSC, Tuberous sclerosis complex; IGFR, Insulin-like growth factor receptor

reported in many LSDs, impairs mitochondrial function and shortens lifespan in yeast [207]. Cumulatively, these results demonstrate the importance of both cytosolic and lysosomal $\mathrm{pH}$ in cellular homeostasis and lifespan.

\section{Current and emerging therapeutic strategies}

Unlike those LSDs, in which the pathologic manifestations occur predominantly in the visceral organs, NCLs pose a significant therapeutic challenge. This is primarily because these diseases manifest mainly in the central nervous system, which is relatively inaccessible due to the blood-brain barrier. Moreover, in most of the NCL forms, the disease onset occurs in early childhood while in others the disease progression is very rapid; for a treatment to be effective, it needs to be initiated as early as possible to prevent significant neuron loss. Because the NCLs are rare diseases, most physicians are unfamiliar with their clinical manifestations. Thus, by the time a genetic diagnosis is firmly established, significant neuron loss has already occurred. Despite these obstacles, progress towards therapeutic development continues to be made.

Among the therapeutic strategies, enzyme replacement therapy (ERT) as well as gene therapy for the CLNs are making steady progress. However, small molecules that are non-toxic, cross the blood-brain-barrier and mimic the function of the mutant gene may be a valuable addition to the other therapeutic strategies. Recently, attempts are being made to identify and characterize thioesterasesmimetic small molecules for the treatment of INCL. Since nucleophilic attack cleaves the thioester linkage in S-palmitoylated proteins (constituents of ceroid), it was reasoned that nucleophilic small molecules, such as cysteamine and $\mathrm{N}$-acetylcysteine, alone or in combination, may have therapeutic potential for INCL. These compounds have been tested first in vitro using cultured cells from 
INCL patients [208]. Based on the results of in vitro studies, a combination of these compounds has been tested in a clinical trial. While the results showed some modest beneficial effects, the patients eventually succumb to the disease [209]. Further efforts to find more potent thioesterases-mimetic small molecules resulted in the identification of a non-toxic small molecule, $N$-tert-(Butyl) hydroxylamine (NtBuHA), which is undergoing pre-clinical testing in $C \ln 1^{-/-}$mice. Treatment of $C \ln 1^{-/-}$mice with oral NtBuHA showed its neuroprotective and lifespan extending effects in these animals [210]. Pre-clinical studies on this small molecule are currently ongoing.

Nonsense mutations in the CLN1 gene can cause INCL and the availability of nonsense- suppressors prompted the testing of at least one such compound, PTC124 [211]. Previously, PTC124 has been tested in vitro using cultured fibroblasts and lymphoblasts from INCL patients to override the premature stop codons resulting from nonsense mutations. However, this treatment yielded only a very modest increase in Ppt1 enzyme activity [212]. This study was followed by the generation of two $C \ln 1$-knock-in (KI) mouse models carrying a lethal nonsense mutation in the $C \ln 1$ gene commonly found in INCL patients in the US [213, 214]. In one study [213], PTC124 was tested in vivo using Ppt1-KI mice, which yielded promising results.

Several ongoing preclinical studies demonstrating the efficacy of Ppt1 enzyme replacement therapy [215-217] as well gene therapy $[218,219]$ continue to pave the way for clinical trials in INCL patients. Recently, it has been reported that a commonly used GAP junction inhibitor, carbenoxolone (CBX), a compound that has been proposed to modify lipid microdomains and corrects defective membrane fluidity in $C l n 3$-deficient endothelial cells, which ameliorates defects in endocytosis, caveolin-1 distribution at the plasma membrane, and Cdc42 activity [220]. Remarkably, treatment of the $C \ln 3$-deficient mice with CBX improved the status of blood-brain-barrier and reduced autofluorescence. Since CBX has been used in humans it has been suggested that CBX and related compounds may have therapeutic potential for patients with CLN3-disease [220]. The current and emerging therapeutic approaches are presented in several excellent articles [221-227]. More specifically, the current therapeutic approaches, which have reached pre-clinical or clinical trials, include CLN1, CLN2, CLN3 and CLN6 diseases (Table 3). Both small and large animal models of various forms of NCLs are being developed. These animal models are likely to be very useful for the preclinical evaluation of novel therapeutic strategies. In this regard, a recently published comprehensive review provides an extensive list of small and large animal models of various NCL forms [228]. Detailed information on various clinical trials can be found in http://clinicaltrials.gov.

\section{Outlook}

The lysosome, with its uniquely acidic $\mathrm{pH}$ and acid hydrolases, is the terminal organelle shared by both endocytic and autophagic pathways of degradation. Since the discovery of the lysosome more than six decades ago, tremendous progress has been made towards identifying the mutated genes underlying LSDs. However, the mechanism(s) by which these mutations impair lysosomal function, causing pathogenesis of the neurodegenerative LSDs, remains poorly understood. Unravelling the complexity and molecular mechanisms that underlie the endo-lysosomal system and delineating the nature of the pathophysiology of neurodegenerative disorders in general remain a formidable challenge. Currently a major objective in the treatment of the LSDs and other common proteinopathic neurodegenerative disorders has been the substrate reduction and clearing of the lysosomes. Although this approach has been moderately successful in treating LSDs that involve the visceral organs, it shows limited benefits at best for the neurodegenerative LSDs like the NCLs. While we continue to learn more about the biological functions of the mutant genes, as related to the pathophysiology of these diseases, the development of mechanism-based treatment may be possible. The development of new vectors for gene therapy is another avenue that may be successful in the foreseeable future. The emerging new roles of the lysosome as they relate to the LSDs and common neurodegenerative diseases may further advance our understanding of the pathogenic mechanisms underlying these diseases and facilitate the development of novel therapeutic strategies. Correlation of basic and clinical data from different therapeutic trials may also contribute to our understanding of these diseases and further identify novel therapeutic targets. It is hoped that in the ensuing years, we will be able to address the following basic questions: (i) what are the critical elements that regulate the endo-lysosomal transport system and what makes this system dysfunctional in neurodegenerative LSDs; (ii) what roles do the lysosomal membrane proteins and their post-translational modifications play in regulating nutrient sensing and mTOR-signaling and how are they dysregulated in neurodegenerative LSDs; (iii) what are the critical elements that regulate membrane fusion between endosome-lysosome and autophagosome-lysosome and (iv) what mechanisms underlie dysregulation of lysosomal acidification in virtually all LSDs as well as in common neurodegenerative diseases. It has recently been proposed that since lysosomal acidification is dysregulated in most LSDs, reacidification of the lysosome may be one of the therapeutic approaches to be considered. Finally, we must aspire to understand what therapeutic interventions can counteract the above-mentioned dysfunctions and what interventions may have a positive impact to ameliorate 
Table 3 A partial list of completed or ongoing NCL clinical trials ${ }^{a}$

\begin{tabular}{|c|c|c|c|c|c|}
\hline $\begin{array}{l}\text { NCL-related } \\
\text { proteins }\end{array}$ & Natural History/ Treatment & $\begin{array}{l}\text { National } \\
\text { Clinical Trial } \\
\text { Number }\end{array}$ & Study Location & Status & Phase \\
\hline \multirow[t]{2}{*}{ CLN1 } & $\begin{array}{l}\text { Single Group Assignment, Procedure: Surgery to implant human CNS stem } \\
\text { cells, single dose } \\
\text { Drug: Immunosuppression for } 12 \text { months post transplant }\end{array}$ & NCT00337636 & $\begin{array}{l}\text { Oregon Health and } \\
\text { Science University } \\
\text { StemCells, Inc. }\end{array}$ & Completed & $\begin{array}{l}\text { Phase } \\
1\end{array}$ \\
\hline & $\begin{array}{l}\text { Single Group Assignment, Interventional, Small Molecule, Cystagon and N- } \\
\text { acetylcysteine }\end{array}$ & NCT00028262 & $\mathrm{NICHD} / \mathrm{NIH}$ & Completed & $\begin{array}{l}\text { Phase } \\
4\end{array}$ \\
\hline \multirow[t]{9}{*}{ CLN2 } & $\begin{array}{l}\text { Single Group Assignment, Biological, ERT (BMN-190 [recombinant human } \\
\text { tripeptidyl peptidase-a (rhTPP1/cerliponase alfa)]), 30-300 mg ICV infusion } \\
\text { administered every other week for at least } 48 \text { weeks }\end{array}$ & NCT01907087 & $\begin{array}{l}\mathrm{NCH}^{\mathrm{b}} \\
\text { University Hamburg- } \\
\text { Eppendorf } \\
\text { Guy's St \& Thomas } \\
\text { NHS Foundation } \\
\text { Trust } \\
\text { Hospital for NHS } \\
\text { Foundation Trust } \\
\text { BioMarin } \\
\text { Pharmaceutical }\end{array}$ & Completed & $\begin{array}{l}\text { Phase } \\
1 / 2\end{array}$ \\
\hline & $\begin{array}{l}\text { Parallel Assignment, Biological, AAVrh.10CUhCLN2 (either } 9.0 \times 10 \wedge 11 \text { or } \\
2.85 \times 10^{\wedge} 11 \text { genome copies) }\end{array}$ & NCT01414985 & WCMC & $\begin{array}{l}\text { Active, not } \\
\text { recruiting }\end{array}$ & $\begin{array}{l}\text { Phase } \\
1 \& 2\end{array}$ \\
\hline & $\begin{array}{l}\text { Parallel Assignment, Genetic: AAVrh.10CUhCLN2 (either } 9.0 \times 10 \wedge 11 \text { or } \\
2.85 \times 10^{\wedge} 11 \text { genome copies) }\end{array}$ & NCT01161576 & WCMC & $\begin{array}{l}\text { Active, not } \\
\text { recruiting }\end{array}$ & $\begin{array}{l}\text { Phase } \\
1\end{array}$ \\
\hline & Parallel Assignment, Genetic: AAV2CUhCLN2 ( $3 \times 10 \wedge 12$ particle units) & NCT00151216 & WCMC & $\begin{array}{l}\text { Active, not } \\
\text { recruiting }\end{array}$ & $\begin{array}{l}\text { Phase } \\
1\end{array}$ \\
\hline & Observational, Case-Only & NCT01035424 & WCMC & $\begin{array}{l}\text { Active, not } \\
\text { recruiting }\end{array}$ & N/A \\
\hline & $\begin{array}{l}\text { Single Group Assignment, Biological: BMN-190, } 300 \text { mg ICV infusion } \\
\text { administered every other week for up to } 240 \text { weeks } \\
\text { Device: Intraventricular access device, surgical implantation of an MRI } \\
\text { compatible ICV access device in the lateral ventricle of the right } \\
\text { hemisphere }\end{array}$ & NCT02485899 & $\begin{array}{l}\text { Columbus, Ohio, } \\
\text { United States } \\
\text { Hamburg, Germany } \\
\text { Rome, Italy } \\
\text { London, United } \\
\text { Kingdom } \\
\text { BioMarin } \\
\text { Pharmaceutical }\end{array}$ & $\begin{array}{l}\text { Active, not } \\
\text { recruiting }\end{array}$ & $\begin{array}{l}\text { Phase } \\
1 / 2\end{array}$ \\
\hline & $\begin{array}{l}\text { Single Group Assignment, Biological: BMN-190 \& recombinant human } \\
\text { tripeptidyl peptidase-1 (rhTPP1), an age-appropriate dose of BMN } 190 \\
\text { administered via intracerebroventricular (ICV) infusion every other week } \\
\text { (qow) for a duration of } 144 \text { weeks } \\
\text { Device: Intraventricular access device, surgical implantation of an MRI } \\
\text { compatible ICV access device in the lateral ventricle of the right } \\
\text { hemisphere }\end{array}$ & NCT02678689 & $\begin{array}{l}\text { Columbus, Ohio, } \\
\text { United States } \\
\text { Hamburg, Germany } \\
\text { Rome, Italy } \\
\text { London, United } \\
\text { Kingdom } \\
\text { BioMarin } \\
\text { Pharmaceutical }\end{array}$ & $\begin{array}{l}\text { Enrolling } \\
\text { by } \\
\text { invitation }\end{array}$ & $\begin{array}{l}\text { Phase } \\
2\end{array}$ \\
\hline & $\begin{array}{l}\text { Observational, Natural History, Primary Outcome: correlation analysis } \\
\text { between genotype (genetic constitution) and baseline [time frame: } 18 \\
\text { months] }\end{array}$ & NCT00151268 & WCMC & Completed & N/A \\
\hline & $\begin{array}{l}\text { Single Group Assignment, Procedure: Surgery to implant human CNS stem } \\
\text { cells (HuCNS-SC) } \\
\text { Drug: Medication to suppress the immune system for } 12 \text { months post } \\
\text { transplant }\end{array}$ & NCT00337636 & $\begin{array}{l}\text { Oregon Health and } \\
\text { Science University } \\
\text { StemCells, Inc. }\end{array}$ & Completed & $\begin{array}{l}\text { Phase } \\
1\end{array}$ \\
\hline \multirow[t]{2}{*}{ CLN3 } & Crossover Assignment, Drug: Small Molecule (Mycophenolate mofetil) & NCT01399047 & $\begin{array}{l}\text { University of } \\
\text { Rochester }\end{array}$ & Completed & $\begin{array}{l}\text { Phase } \\
2\end{array}$ \\
\hline & Natural History, Cohort & NCT03307304 & $\mathrm{NICHD} / \mathrm{NIH}$ & Recruiting & \\
\hline \multirow[t]{2}{*}{ CLN6 } & $\begin{array}{l}\text { Observational/Natural History, Primary Outcome: disease progression [time } \\
\text { frame: } 3 \text { years] }\end{array}$ & NCT03285425 & $\mathrm{NCH}$ & Recruiting & N/A \\
\hline & $\begin{array}{l}\text { Single Group Assignment, Gene Therapy, Drug:ScAW9.CB.CLN6 } \\
\text { administered by intrathecal injection }\end{array}$ & NCT02725580 & $\mathrm{NCH}$ & Recruiting & $\begin{array}{l}\text { Phase } \\
1 / 2\end{array}$ \\
\hline
\end{tabular}


Table 3 A partial list of completed or ongoing NCL clinical trials ${ }^{a}$ (Continued)

\begin{tabular}{|c|c|c|c|c|c|}
\hline $\begin{array}{l}\text { NCL-related } \\
\text { proteins }\end{array}$ & Natural History/ Treatment & $\begin{array}{l}\text { National } \\
\text { Clinical Trial } \\
\text { Number }\end{array}$ & Study Location & Status & Phase \\
\hline \multirow[t]{2}{*}{$\begin{array}{l}\text { General } \\
\text { Batten } \\
\text { Disease }\end{array}$} & $\begin{array}{l}\text { Observational [Patient Registry], Cohort, } \\
\text { Primary Outcome measures: Refinement and validation of UBDRS, The } \\
\text { natural history of Batten Disease [both time frames: } 10 \text { years] }\end{array}$ & NCT01873924 & $\begin{array}{l}\text { University of } \\
\text { Rochester }\end{array}$ & Recruiting & N/A \\
\hline & $\begin{array}{l}\text { Observational, Cross-Sectional Primary Outcome measure: sleep } \\
\text { disturbance } \\
\text { Secondary Outcome measure: epilepsy onset, Blindness [both time frames: } \\
1 \text { year] }\end{array}$ & NCT01966757 & $\mathrm{NCH}$ & Completed & N/A \\
\hline
\end{tabular}

${ }^{\mathrm{a}}$ For a complete list of clinical trials go to: https://Clinicaltrials.gov

${ }^{\mathrm{b}} \mathrm{NCH}$, Nationwide Children's Hospital

'WCMC,Weill College of Medicine, Cornell University

${ }^{\mathrm{d}}$ NICHD, National Institute of Child Health and Human Development, NIH, National Institutes of Health

these defects. Our efforts to answer the above questions may enable us to develop effective therapeutics for the neurodegenerative LSDs, which mostly affect children. We anticipate that advances in our understanding of the disease mechanism(s) coupled with the improved methods of restoring normal lysosomal function by small molecules that cross the blood-brain barrier, the development of novel strategies to deliver the missing gene product, and the generation of vectors to deliver gene therapy to the brain may lead to effective treatments for these devastating diseases.

\section{Conclusion}

In summary, endolysosomal and autophagic dysfunction underlie most of the LSDs and neurodegeneration is a devastating manifestation in most of these diseases. Neuronal ceroid lipofuscinoses are the most common neurodegenerative LSDs that mostly affect children. Although the mutant genes underlying each of the $13 \mathrm{NCL}$ forms have been identified and characterized, the physiological functions of the gene products remain poorly understood. Consequently, the pathogenic mechanism(s) of the NCLs remain elusive despite intense investigations. While major advances towards understanding the pathophysiology of the NCLs have been achieved more research is needed to arrive at the finish line. Despite the lack of mechanistic understanding of these diseases, progress is being made towards the development of effective therapies. In this regard, animal models are a very useful tool. Although replacement of the missing gene product and gene therapy approaches have made significant progress, and some are in clinical or pre-clinical trials, efforts to develop mechanism-based therapeutics should continue. Another area of research that needs more attention is the search for biomarkers for each of the NCL forms. The emerging new roles of the lysosome is an area of research that promises to yield new information on all LSDs including the NCLs.

\section{Abbreviations}

CLEAR: Coordinated lysosomal expression and regulation; CLN: Ceroid

lipofuscinosis neuronal; CSPa: Cysteine string protein alpha; CTSD: Cathepsin D;
ER: Endoplasmic reticulum; ESCRT: Endosomal sorting complex required for transport; GAP-43: Growth associated protein 43; INCL: Infantile neuronal ceroid lipofuscinosis; JNCL: Juvenile NCL; KCTD7: Potassium channel tetramerization domain-containing protein 7; LINCL: Late infantile neuronal ceroid lipofuscinosis; LSDs: Lysosomal storage diseases; mTORC1: Mechanistic (mammalian) target of rapamycin complex 1; NCLs: Neuronal ceroid lipofuscinoses; NPC1: Niemann pick C1; PPT1: Palmitoyl-protein thioesterases-1; SCMAS: Subunit c of mitochondrial ATP synthase; SNAP25: 25-kDa Synaptosomal protein; SNARE: Soluble N-ethylmaleimide-sensitive attachment receptor; SV: Synaptic vesicle; TF: Transcription factor; TFEB: Transcription factor EB;TPP1, Tripeptidyl peptidase 1; UPR: Unfolded protein response;

VAMP2: Vesicle-associated membrane protein 2; v-ATPase: Vacuolar adenosine triphosphatase

\section{Acknowledgements}

This work was supported in full by the intramural program of the Eunice Kennedy Shriver National Institute of Child Health and Human Development, National Institutes of Health. The authors regret not being able to cite all the literature in the field due to limited space and we apologize to those authors whose publications are not included in this review. We would like to thank Drs. Janice Y. Chou and Sondra W. Levin for critical review of the manuscript and for providing valuable suggestions during the preparation of this manuscript.

\section{Funding}

The work devoted to generating this manuscript was supported in full by the intramural program of the Eunice Kennedy Shriver National Institute of Child Health and Human Development (NICHD), National Institutes of Health $(\mathrm{NIH})$. No external funding was received by any of the authors.

\section{Availability of data and materials}

Not applicable.

\section{Authors' contributions}

ABM wrote the first draft of the manuscript. The manuscript was further revised by $A B M$ along with input from APA, MBB, TS, SC, AM and ZZ. Copy editing was performed by SC and MBB. All authors contributed in revising the initial draft, as well as reviewing, preparing and approving the final draft of the manuscript for submission.

\section{Authors' information}

Not applicable

Ethics approval and consent to participate Not applicable.

\section{Consent for publication}

Not applicable.

Competing interests

All authors declare that they have no competing interests. 


\section{Publisher's Note}

Springer Nature remains neutral with regard to jurisdictional claims in published maps and institutional affiliations.

\section{Author details \\ 'Section on Developmental Genetics, Program on Endocrinology and Molecular Genetics, Eunice Kennedy Shriver National Institute of Child Health and Human Development, The National Institutes of Health, Bethesda, Maryland 20892-1830, USA. ${ }^{2}$ Present address: Institute of Psychiatry and Neuroscience, Xinxiang Medical University, Xinxiang 453003, Henan, China.}

\section{Received: 12 July 2018 Accepted: 4 December 2018}

\section{Published online: 16 January 2019}

\section{References}

1. De Duve C, Pressman BC, Gianetto R, Wattiaux R, Appelmans F. Tissue fractionation studies. 6 . Intracellular distribution patterns of enzymes in ratliver tissue. Biochem J. 1955;60:604-17.

2. Luzio JP, Parkinson MD, Gray SR, Bright NA. The delivery of endocytosed cargo to lysosomes. Biochem Soc Trans. 2009;37:1019-21. https://doi.org/10. 1042/BST0371019.

3. Bento CF, Renna M, Ghislat G, Puri C, Ashkenazi A, Vicinanza M, Menzies FM, Rubinsztein DC. Mammalian autophagy: How does it work? Annu Rev Biochem. 2016;85:685-13. https://doi.org/10.1038/ncomms11803.

4. Mizushima N, Komatsu M. Autophagy: renovation of cells and tissues. Cell. 2011;147:728-41. https://doi.org/10.1016/j.cell.2011.10.026Ballabio.

5. Ballabio A, Gieselmann V. Lysosomal disorders: from storage to cellular damage. Biochim Biophys Acta. 1793;2009:684-96. https://doi.org/10.1016/j. bbamcr.2008.12.001.

6. Parenti G, Andria G, Ballabio A. Lysosomal storage diseases: from pathophysiology to therapy. Annu Rev Med. 2015;66:471-86. https://doi.org/ 10.1146/annurev-med-122313-085916.

7. Platt FM, Boland B, van der Spoel AC. The cell biology of disease: Iysosomal storage disorders: the cellular impact of lysosomal dysfunction. J Cell Biol. 2012:199:723-34. https://doi.org/10.1083/jcb.201208152.

8. Proia RL, Wu YP. Blood to brain to the rescue. J Clin Invest. 2004;113:1108-10. https://doi.org/10.1172/JCI21476.

9. Saftig P, Klumperman J. Lysosome biogenesis and lysosomal membrane proteins: trafficking meets function. Nat Rev Mol Cell Biol. 2009;10:623-35. https://doi.org/10.1038/nrm2745.

10. Schwake M, Schroder B, Saftig P. Lysosomal membrane proteins and their central role in physiology. Traffic. 2013;14:739-48. https://doi.org/10.1111/tra.12056.

11. Raiborg C, Stenmark H. The ESCRT machinery in endosomal sorting of ubiquitylated membrane proteins. Nature. 2009;458:445-52. https://doi.org/ 10.1038/nature07961

12. Settembre C, Fraldi A, Medina DL, Ballabio A. Signals from the lysosome: a control centre for cellular clearance and energy metabolism. Nat Rev Mol Cell Biol. 2013:14:283-96. https://doi.org/10.1038/nrm3565.

13. Efeyan A, Comb WC, Sabatini DM. Nutrient-sensing mechanisms and pathways. Nature. 2015;517:302-10. https://doi.org/10.1038/nature14190.

14. Schultz ML, Tecedor L, Chang M, Davidson BL. Clarifying lysosomal storage diseases. Trends Neurosci. 2011;34:401-10. https://doi.org/10.1016/j.tins.2011. 05.006.

15. Braulke T, Bonifacino JS. Sorting of lysosomal proteins. Biochim Biophys Acta. 1793;2009:605-14. https://doi.org/10.1016/j.bbamcr.2008. 10.016 .

16. Seranova E, Connolly KJ, Zatyka M, Rosenstock TR, Barrett T, Tuxworth RI, et al. Dysregulation of autophagy as a common mechanism in lysosomal storage diseases. Essays Biochem. 2017;61:733-49. https://doi.org/10.1042/ EBC20170055

17. Di Fiore PP, von Zastrow M. Endocytosis, signaling, and beyond. Cold Spring Harb Perspect Biol 2014; 6. pii: a016865. https://doi.org/10.1101/cshperspect. a016865

18. Gruenberg J. The endocytic pathway: a mosaic of domains. Nat Rev Mo Cell Biol. 2001;2:721-30. https://doi.org/10.1038/35096054.

19. Scott CC, Vacca F, Gruenberg J. Endosome maturation, transport and functions. Semin Cell Dev Biol. 2014;31:2-10. https://doi.org/10.1016/j. semcdb.2014.03.034

20. Attar N, Cullen PJ. The retromer complex. Adv Enzyme Regul. 2010;50:21636. https://doi.org/10.1016/j.advenzreg.2009.10.002.
21. McGough IJ, Cullen PJ. Recent advances in retromer biology. Traffic. 2011; 12:963-71. https://doi.org/10.1111/j.1600-0854.2011.01201.x.

22. Kowal J, Tkach M, Théry C. Biogenesis and secretion of exosomes. Curr Opin Cell Biol. 2014;29:116-25. https://doi.org/10.1016/j.ceb.2014.05.004.

23. Pfeffer SR. Rab GTPases: master regulators that establish the secretory and endocytic pathways. Mol Biol Cell. 2017;28:712-5. https://doi.org/10.1091/ mbc.E16-10-0737.

24. Wang YC, Ysselstein D, Kraine D. Mitochondria-lysosome contacts regulate mitochondrial fission via Rab GTP hydrolysis. Nature. 2018;554:382-6. https:// doi.org/10.1038/nature25486

25. Holopainen JM, Saarikoski J, Kinnunen PKJ, Jarvela I. Elevated lysosomal pH in neuronal ceroid lipofuscinoses (NCLs). Eur J Biochem. 2001;268:5851-6. https://doi.org/10.1046/j.0014-2956.2001.02530.x.

26. Kyttälä A, Lahtinen U, Braulke T, Hofmann SL. Functional biology of the neuronal ceroid lipofuscinoses (NCL) proteins. Biochim Biophys Acta. 1762; 2006:920-33. https://doi.org/10.1016/j.bbadis.2006.05.007.

27. Forgac M. Vacuolar ATPases: rotary proton pumps in physiology and pathophysiology. Nat Rev Mol Cell Biol. 2007;8:917-29. https://doi.org/10. 1038/nrm2272.

28. Nishi T, Forgac M. The vacuolar H-ATPases—nature's most versatile proton pumps. Nat Rev Mol Cell Biol. 2002;3:94-103. https://doi.org/10.1038/nrm729.

29. Mindell JA. Lysosomal acidification mechanisms. Annu Rev Physiol. 2012;74: 69-86. https://doi.org/10.1146/annurev-physiol-012110-142317.

30. Chaudhry FA, Boulland JL, Jenstad M, Bredahl MK, Edwards RH. Pharmacology of neurotransmitter transport into secretory vesicles. Handb Exp Pharmacol. 2008;184:77-106. https://doi.org/10.1007/978-3540-74805-2 4

31. Mellman I, Fuchs R, Helenius A. Acidification of the endocytic and exocytic pathways. Annu Rev. Biochem. 1986;55:663-700. https://doi.org/10.1146/ annurev.bi.55.070186.003311.

32. Heuser J. Changes in lysosome shape and distribution correlated with changes in cytoplasmic pH. J Cell Biol. 1989:108:855-64. https://doi.org/10. 1083/jcb.108.3.855

33. Bourdenx M, Daniel J, Genin E, Soria FN, Blanchard-Desce M, Bezard E, et al. Nanoparticles restore lysosomal acidification defects: Implications for Parkinson and other lysosomal-related diseases. Autophagy. 2016;12:472-83. https://doi.org/10.1080/15548627.2015.1136769.

34. Jahn R, Lang T, Sudhof TC. Membrane Fusion. Cell. 2003;12:519-33. https:// doi.org/10.1016/S0092-8674(03)00112-0.

35. Rizo J, Südhof TC. The membrane fusion enigma: SNAREs, Sec1/Munc 18 proteins, and their accomplices---guilty as charged? Annu Rev Cell Dev Biol. 2012;28:279-308. https://doi.org/10.1146/annurev-cellbio$101011-155818$

36. Baars TL, Petri S, Peters $C$, Mayer A. Role of the $\mathrm{V}$-ATPase in regulation of the vacuolar fission-fusion equilibrium. Mol. Biol. Cell. 2007;18:3873-82. https:// doi.org/10.1091/mbc.E07-03-0205.

37. Moreau K, Ravikumar B, Renna M, Puri C, Rubinsztein DC. Autophagosome precursor maturation requires homotypic fusion. Cell. 2011;146:303-17. https://doi.org/10.1016/j.cell.2011.06.023.

38. Boya P, Reggiori F, Codogno P. Emerging regulation and function of autophagy. Nat Cell Biol. 2013;15:713-20. https://doi.org/10.1038/ncb2788.

39. Galluzzi L, Baehrecke EH, Ballabio A, Boya P, Bravo-San Pedro JM, Cecconi F, et al. Molecular definitions of autophagy and related processes. EMBO J. 2017;36:1811-36. https://doi.org/10.15252/embj.201796697.

40. Rubinsztein DC. The roles of intracellular protein-degradation pathways in neurodegeneration. Nature. 2006;443:780-6. https://doi.org/10.1038/ nature05291.

41. Lieberman AP, Puertollano R, Raben N, Slaugenhaupt S, Walkley SU, et al. Autophagy in lysosomal storage disorders. Autophagy. 2012;8:719-30. https://doi.org/10.4161/auto.19469.

42. Ballabio A. Disease pathogenesis explained by basic science: Iysosomal storage diseases as autophagocytic disorders. Int J Clin Pharmacol Ther. 2009;47(1):S34-8.

43. Lie $P$, Nixon RA. Lysosome trafficking and signaling in health and neurodegenerative diseases. Neurobiol Dis. 2018; pii: S0969-9961(18)301530. https://doi.org/10.1016/j.nbd.2018.05.015.

44. Nixon RA. The role of autophagy in neurodegenerative diseases. Nat Med 2013:19:983-97. https://doi.org/10.1038/nm.3232.

45. Frake RA, Ricketts T, Menzies FM, Rubinsztein DC. Autophagy and neurodegeneration. J Clin Invest. 2015:125:65-74. https://doi.org/10.1172/ JCI73944. 
46. Simonati A, Pezzini F, Moro F, Santorelli FM. Neuronal ceroid lipofuscinosis: The increasing spectrum of an old disease. Curr Mol Med. 2014;14:1043-51. https://doi.org/10.2174/1566524014666141010154913.

47. Carcel-Trullols J, Kovacs AD, Pearce DA. Cell biology of the NCL proteins: what they do and don't do. Biochim Biophys Acta. 1852;2015:2242-55. https://doi.org/10.1016/j.bbadis.2015.04.027.

48. Cooper JD, Tarczyluk MA, Nelvagal HR. Towards a new understanding of NCL pathogenesis. Biochim Biophys Acta. 2015;1852:2256-61. https://doi. org/10.1016/j.bbadis.2015.05.014.

49. Kollmann K, Uusi-Rauva K, Scifo E, Tyynelä J, Jalanko A, Braulke T. Cell biology and function of neuronal ceroid lipofuscinosis-related proteins. Biochim Biophys Acta. 2013;1832:1866-81. https://doi.org/10.1016/j.bbadis. 2013.01.019.

50. Mole SE, Cotman SL. Genetics of the neuronal ceroid lipofuscinoses (Batten disease). Biochim Biophys Acta. 1852;2015:2237-41. https://doi.org/10.1016/j. bbadis.2015.05.011.

51. Radke J, Stenzel W, Goebel HH. Human NCL neuropathology. Biochim Biophys Acta. 1852;2015:2262-6. https://doi.org/10.1016/j.bbadis.2015.05.007.

52. Haltia M, Goebel HH. The neuronal ceroid-lipofuscinoses: a historical introduction. Biochim Biophys Acta. 1832;2003:1795-800. https://doi.org/10. 1016/j.bbadis.2012.08.012.

53. Sardiello M, Palmieri M, di Ronza A, Medina DL, Valenza M, Gennarino VA, et al. A gene network regulating lysosomal biogenesis and function. Science. 2009;325:473-7. https://doi.org/10.1126/science.1174447.

54. Carroll B, Dunlop EA. The lysosome: a crucial hub for AMPK and mTORC1 signaling. Biochem J. 2017;474:1453-66. https://doi.org/10.1042/ BCJ20160780.

55. Settembre C, Zoncu R, Medina DL, Vetrini F, Erdin S, Erdin S, et al. A lysosome-to-nucleus signalling mechanism senses and regulates the lysosome via mTOR and TFEB. EMBO J. 2012;31:1095-108. https://doi.org/10. 1038/emboj.2012.32

56. Perera RM, Zoncu R. The lysosome as a regulatory Hub. Annu Rev Cell Dev Biol. 2016;32:223-53. https://doi.org/10.1146/annurev-cellbio-111315-125125.

57. Camp LA, Hofmann SL. Purification and properties of a palmitoyl-protein thioesterase that cleaves palmitate from H-Ras. J Biol Chem. 1993;268:22566-74.

58. Vesa J, Hellsten E, Verkruyse LA, Camp LA, Rapola J, Santavuori P, et al. Mutatons in the palmitoyl protein thioesterases gene causing infantile neuronal ceroid lipofuscinosis. Nature. 1995;376:584-7. https://doi.org/10 1038/376584a0

59. Santavuori P. Neuronal ceroid-lipofuscinoses in childhood. Brain Dev. 1988; 10:80-3. https://doi.org/10.1016/S0387-7604(88)80075-5.

60. Kousi M, Anttila V, Schulz A, Calafato S, Jakkula E, Riesch E, et al. Novel mutations consolidate KCTD7 as a progressive myoclonus epilepsy gene. J Med Genet. 2012;49:391-9. https://doi.org/10.1136/jmedgenet-2012-100859.

61. Lu JY, Verkruyse LA, Hofmann SL. Lipid thioesters derived from acylated proteins accumulate in infantile neuronal ceroid lipofuscinosis: correction of the defect in lymphoblasts by recombinant palmitoyl-protein thioesterase. Proc Natl Acad Sci U S A. 1996;93:10046-50. https://doi.org/10.1073/pnas.93.19.10046.

62. Camp LA, Verkruyse LA, Afendis SJ, Slaughter CA, Hofmann SL. Molecular cloning and expression of palmitoyl-protein thioesterase. J Biol Chem. 1994; 269:23212-9.

63. Linder ME, Deschenes RJ. Palmitoylation: policing protein stability and traffic. Nat Rev Mol Cell Biol. 2007:8:74-84. https://doi.org/10.1038/nrm2084.

64. Fukata Y, Fukata M. Protein palmitoylation in neuronal development and synaptic plasticity. Nat Rev Neurosci. 2010;11:161-75. https://doi.org/10. 1038/nrn2788

65. Khan A, Chieng KS, Baheerathan A, Hussain N, Gosalakkal J. Novel CLN1 mutation with atypical juvenile neuronal ceroid lipofuscinosis. J Pediatr Neurosci. 2013;8:49-51. https://doi.org/10.4103/1817-1745.111424.

66. Mitchison HM, Hofmann SL, Becerra CH, Munroe V, Lake BD, Crow YJ, et al. Mutations in the palmitoyl-protein thioesterases gene (PPT; CLN1) causing juvenile neuronal ceroid lipofuscinosis with granular osmiophilic deposits. Hum Mol Genet. 1998;7:291-7. https://doi.org/10.1093/hmg/7.2.291.

67. Henderson MX, Wirak GS, Zhang YQ, Dai F, Ginsberg SD, Dolzhanskaya N, et al. Neuronal ceroid lipofuscinosis with DNAJC5/CSPa mutation has PPT pathology and exhibit aberrant protein palmitoylation. Acta Neuropathol. 2016;131:621-37. https://doi.org/10.1007/s00401-015-1512-2.

68. Bagh MB, Peng S, Chandra G, Zhang Z, Singh SP, Pattabiraman N, et al. Misrouting of v-ATPase subunit V0a1 dysregulates lysosomal acidification in a neurodegenerative lysosomal storage disease model. Nat Commun. 2017; 8:14612. https://doi.org/10.1038/ncomms14612.
69. Hetz C, Saxena S. ER stress and the unfolded protein response in neurodegeneration. Nat Rev Neurol. 2017;13:477-91. https://doi.org/10. 1038/nrneurol.2017.99.

70. Sano R, Annunziata I, Patterson A, Moshiach S, Gomero E, Opferman J, et al. GM1-ganglioside accumulation at the mitochondria-associated ER membranes links ER stress to $\mathrm{Ca}(2+)$-dependent mitochondrial apoptosis. Mol Cell. 2009;36: 500-11. https://doi.org/10.1016/j.molcel.2009.10.021.

71. Zhang Z, Lee YC, Kim SJ, Choi MS, Tsai PC, Xu Y, et al. Palmitoyl-protein thioesterase-1 deficiency mediates the activation of the unfolded protein response and neuronal apoptosis in INCL. Hum Mol Genet. 2006;15:337-46. https://doi.org/10.1093/hmg/ddi451.

72. Sprenkle NT, Sims SG, Sanchez CL, Meares GP. Endoplasmic reticulum stress and inflammation in the central nervous system. Mol Neurodegener. 2017; 12:42. https://doi.org/10.1186/s13024-017-0183-y.

73. Kim SJ, Zhang Z, Hitomi E, Lee YC, Mukherjee AB. Endoplasmic reticulum stressinduced caspase-4 activation mediates apoptosis and neurodegeneration in INCL. Hum Mol Genet. 2006;15:1826-34. https:/doi.org/10.1093/hmg/ddl105.

74. Wei H, Kim SJ, Zhang Z, Tsai PC, Wisniewski KE, Mukherjee AB. ER and oxidative stress are common mediators of apoptosis in both neurodegenerative and non-neurodegenerative lysosomal storage disorders and are alleviated by chemical chaperones. Hum Mol Genet. 2008;17:469-77. https://doi.org/10. 1093/hmg/ddm324.

75. Marotta D, Tinelli E, Mole SE. NCLs and ER: A stressful relationship. Biochim Biophys Acta. 1863;2017:1273-81. https://doi.org/10.1016/j. bbadis.2017.04.003.

76. Sleat DE, Gin RM, Sohar I, Wisniewski K, Sklower-Brooks S, Pullarkat RK, et al. Mutational analysis of the defective protease in classic late-infantile neuronal ceroid lipofuscinosis, a neurodegenerative lysosomal storage disorder. Am J Hum Genet. 1999;64:1511-23. https://doi.org/10.1086/302427.

77. Golabek AA, Kida E, Walus M, Wujek P, Mehta P, Wisniewski KE. Biosynthesis, glycosylation and enzyme processing in vivo of human tripeptidyl peptidase I. Jiol Chem. 2003;278:7135-45. https://doi.org/10.1074/jbc.M211872200.

78. Vines DJ, Warburton MJ. Classical late infantile neuronal ceroid lipofuscinosis fibroblasts are deficient in lysosomal tripeptidyl peptidase I. FEBS Lett. 1999; 443:131-5. https://doi.org/10.1016/S0014-5793(98)01683-4.

79. Guhaniyogi J, Sohar I, Das K, Stock AM, Lobel P. Crystal structure and autoactivation pathway of the precursor form of human tripeptidylpeptidase 1, the enzyme deficient in late infantile ceroid lipofuscinosis. J Biol Chem. 2009;284:3985-97. https://doi.org/10.1074/jbc.M806943200.

80. Kuizon S, Di Maiuta K, Walus M, Jenkins EC, Kuizon M, Kida E, et al. A critical tryptophan and $\mathrm{Ca} 2$ + in activation and catalysis of TPPI, the enzyme deficient in classic late-infantile neuronal ceroid lipofuscinosis. PLoS One. 2010;5:e11929. https://doi.org/10.1371/journal.pone.0011929.

81. Kurachi Y, Oka A, Itoh M, Mizuguchi M, Hayashi M, Takashima S. Distribution and development of CLN2 protein, the late-infantile neuronal ceroid lipofuscinosis gene product. Acta Neuropathol. 2001;102:20-6. https://doi. org/10.1007/s004010000321.

82. Koike M, Shibata M, Ohsawa Y, Kametaka S, Waguri S, et al. The expression of tripeptidyl peptidase I in various tissues of rats and mice. Arch Histol Cytol. 2002;65:219-32. https://doi.org/10.1679/aohc.65.219.

83. Williams RE, Adams HR, Blohm M, Cohen-Pfeffer JL, de Los RE, Denecke J, et al. Management strategies for CLN2 disease. Pediatr Neurol. 2017;69:102-12. https:/doi.org/10.1016/j.pediatrneurol.2017.01.034

84. Vidal-Donet JM, Cárcel-Trullols J, Casanova B, Aguado C, Knecht E. Alterations in ROS activity and lysosomal pH account for distinct patterns of macroautophagy in LINCL and JNCL fibroblasts. PLoS One. 2013;8:e55526. https://doi.org/10.1371/journal.pone.0055526.

85. Wang J, Yang $X$, Zhang J. Bridges between mitochondrial oxidative stress, ER-Stress and mTOR signaling in pancreatic $\beta$ cells. Cell Signal. 2016;28: 1099-104. https://doi.org/10.1016/j.cellsig.2016.05.007.

86. Lojewski X, Staropoli JF, Biswas-Legrand S, Simas AM, Haliw L, Selig MK, et al. Human iPSC models of neuronal ceroid lipofuscinosis capture distinct effects of TPP1 and CLN3 mutations on the endocytic pathway. Hum Mol Genet. 2014;23:2005-22. https://doi.org/10.1093/hmg/ddt596.

87. Sleat DE, Tannous A, Sohar I, Wiseman JA, Zheng H, Qian M, et al. Proteomic analysis of brain and cerebrospinal fluid from three major forms of neuronal ceroid lipofuscinosis reveals potential biomarkers. J Proteome Res. 2017;16:3787-804. https://doi.org/10.1021/acs.jproteome.7b00460.

88. International Batten Disease Consortium. Isolation of a novel gene underlying Batten disease, CLN3. Cell. 1995;82:949-57. https://doi.org/10. 1016/0092-8674(95)90274-0. 
89. Nugent T, Mole SE, Jones DT. The transmembrane topology of Batten disease protein CLN3 determined by consensus computational prediction constrained by experimental data. FEBS Lett. 2008;582:1019-24. https://doi org/10.1016/j.febslet.2008.02.049.

90. Ratajczak E, Petcherski A, Ramos-Moreno J, Ruonala MO. FRET-assisted determination of CLN3 membrane topology. PLoS One. 2014;22:e102593. https://doi.org/10.1371/journal.pone.0102593.

91. Mole SE, Karaa A, Staropoli JF, Sims KB. Neuronal ceroid lipofuscinosis: impact of recent genetic advances and expansion of the clinicopathologic spectrum. Curr Neurol Neurosci Rep. 2013;13:366. https://doi.org/10.1007/ s11910-013-0366-z

92. Chan $\mathrm{CH}$, Mitchison HM, Pearce DA. Transcript and in silico analysis of CLN3 in juvenile neuronal ceroid lipofuscinosis and associated mouse models. Hum Mol Genet. 2008;17:3332-9. https://doi.org/10.1093/hmg/ddn228.

93. Chattopadhyay S, Pearce DA. Neural and extraneural expression of the neuronal ceroid lipofuscinoses genes CLN1, CLN2, and CLN3: functional implications for CLN3. Mol Genet Metab. 2000;71:207-11. https://doi.org/10. 1006/mgme.2000.3056

94. Castaneda JA, Pearce DA. Identification of alpha-fetoprotein as an autoantigen in juvenile Batten disease. Neurobiol Dis. 2008;29:92-102. https://doi.org/10.1016/j.nbd.2007.08.007.

95. Chattopadhyay S, Ito M, Cooper JD, Brooks Al, Curran TM, Powers JM, et al. An autoantibody inhibitory to glutamic acid decarboxylase in the neurodegenerative disorder Batten disease. Hum. Mol. Genet. 2002;11:142131. https://doi.org/10.1093/hmg/11.12.1421.

96. Hofman I, Van der Wal A, Dingemans K, Becker A. Cardiac pathology in neuronal ceroid lipofuscinoses - a clinicopathologic correlation in three patients. Eur J Paediatr Neurol. 2001;5:213-7. https://doi.org/10.1053/ejpn. 2000.0465

97. Haskell RE, Carr CJ, Pearce DA, Bennett MJ, Davidson BL. Batten Disease: Evaluation of CLN3 mutations on protein localization and function. Hum Mol Genet. 2000;9:735-44. https://doi.org/10.1093/hmg/9.5.735.

98. Jarvela I, Lehtovirta M, Tikknen R, Kyttala A, Jalenko A. Defective intracellular transport of CLN3 is the molecular basis of Batten disease (JNCL). Hum Mol Genet. 1999;8:1091-8. https://doi.org/10.1093/hmg/8.6.1091.

99. Jarvela I, Sainio M, Rantamaki T, Olkkonen VM, Carpen O, Peltonen L, et al. Biosynthesis and intracellular targeting of the CLN3 protein defective in Batten disease. Hum Mol. Genet. 1998;7:85-90. https://doi. org/10.1093/hmg/7.1.85.

100. Cao Y, Staropoli JF, Biswas S, Espinola JA, MacDonald ME, Lee JM, et al. Distinct early molecular responses to mutations causing VLINCL and JNCL presage ATP synthase subunit C accumulation in cerebellar cells. PLoS One. 2011;6:e17118. https://doi.org/10.1371/journal.pone.0017118.

101. Metcalf DJ, Calvi AA, Seaman MN, Mitchison HM, Cutler DF. Loss of the Batten disease gene CLN3 prevents exit from the TGN of the mannose 6phosphate receptor. Traffic. 2008;9:1905-14. https://doi.org/10.1111/j.16000854.2008.00807.x.

102. Cao Y, Espinola JA, Fossale E, Massey AC, Cuervo AM, MacDonald ME, et al Autophagy is disrupted in a knock-in mouse model of juvenile neuronal ceroid lipofuscinosis. J Biol Chem. 2006;281:20483-93. https://doi.org/10. 1074/jbc.M602180200.

103. Chandrachud U, Walker MW, Simas AM, Heetveld S, Petcherski A, Klein M, et al. Unbiased cell-based screening in a neuronal cell model of Batten disease highlights an interaction between Ca2+ homeostasis, autophagy and CLN3 protein function. J Biol Chem. 2015;290:14361-80. https://doi.org/ 10.1074/jbc.M114.621706.

104. Zhu X, Huang Z, Chen Y, Zhou J, Hu S, Zhi Q, et al. Effect of CLN3 silencing by RNA interference on the proliferation and apoptosis of human colorectal cancer cells. Biomed Pharmacother. 2014;68:253-8. https://doi.org/10.1016/j. biopha.2013.12.010.

105. Rusyn E, Mousallem T, Persaud-Sawin DA, Miller S, Boustany RM. CLN3p impacts galactosylceramide transport, raft morphology, and lipid content. Pediatr Res. 2008;63:625-31. https://doi.org/10.1203/PDR Ob013e31816fdc17.

106. Palmer DN. The relevance of the storage of subunit $c$ of ATP synthase in different forms and models of Batten disease (NCLs). Biochim Biophys Acta. 2015;1852:2287-91. https://doi.org/10.1016/j.bbadis.2015.06.014.

107. Palmieri M, Pal R, Nelvagal HR, Lotfi P, Stinnett GR, Seymour MI, et al. mTORC1-independent TFEB activation via Akt inhibition promotes cellular clearance in neurodegenerative storage diseases. Nat Commun. 2017:8: 14338. https://doi.org/10.1038/ncomms14338.
108. Noskova V, Stranecky H, Hartmannova A, Pristoupilova V, Baresova R. Mutations in DNAJC5, encoding cysteine-string protein alpha, cause autosomal-dominant adult-onset neuronal ceroid lipofuscinosis. Am J Hum Genet. 2011;89:241-52. https://doi.org/10.1016/j.ajhg.2011.07.003.

109. Simonati A, Pezzini F, Moro F, Santorelli FM. Neuronal ceroid lipofuscinosis: The increasing spectrum of an old disease. Curr. Mol. Med. 2014;14:1043-51. https://doi.org/10.2174/1566524014666141010154913.

110. Smith KR, Dahl HH, Canafoglia L, Andermann E, Damiano J, Morbin M, et al. Cathepsin F mutations cause Type B Kufs disease, an adult-onset neuronal ceroid lipofuscinosis. Hum Mol Genet. 2013;22:1417-23. https://doi.org/10. 1093/hmg/dds558.

111. Peters J, Tittger A, Weisner R, Knabbe J, Zunke F, Rothaug M, et al. Lysosomal integral membrane protein type-2 (LIMP-2/SCARB2) is a substrate of cathepsin$\mathrm{F}$, a cysteine protease mutated in type-B-Kufs-disease. Biochem Biophys Res Commun. 2015;457:334-40. https://doi.org/10.1016/j.bbrc.2014.12.111.

112. Berkovic SF, Staropoli JF, Carpenter S, Oliver KL, Kmoch S, Anderson GW, et al. ANCL Gene Discovery Consortium. Neurol. 2016:87:579-84. https://doi. org/10.1212/WNL.0000000000002943.

113. Donnelier J, Braun JEA. CSPa-chaperoning presynaptic proteins. Front Cell Neurosci. 2014;8:116. https://doi.org/10.3389/fncel.2014.00116.

114. Chandra S, Gallardo G, Fernández-Chacón R, Schlüter OM, Südhof TC. Alpha synuclein cooperates with CSPalpha in preventing neurodegeneration. Cell. 2005;123:383-96. https://doi.org/10.1016/j.cell.2005.09.028.

115. Sharma M, Burré J, Bronk P, Zhang Y, Xu W, Südhof TC. CSPalpha knockout causes neurodegeneration by impairing SNAP-25 function. EMBO J. 2012;31: 829-41. https://doi.org/10.1038/emboj.2011.467.

116. Savukoski M, Klockars T, Holmberg V, Santavuori P, Lander ES, Peltonen L. CLN5, a novel gene encoding a putative transmembrane protein mutated in Finnish variant late infantile neuronal ceroid lipofuscinosis. Nat Genet. 1998;19:286-8. https://doi.org/10.1038/975.

117. Pineda-Trujillo N, Cornejo W, Carrizosa J, Wheeler RB, Munera S, Valencia A, et al. A CLN5 mutation causing an atypical neuronal ceroid lipofuscinosis of juvenile onset. Neurology. 2005;64:740-2. https://doi.org/10.1212/01.WNL. 0000151974.44980.F1.

118. Schmiedt ML, Blom T, Blom T, Kopra O, Wong A, von Schantz-Fant C, et al. Cln5-deficiency in mice leads to microglial activation, defective myelination and changes in lipid metabolism. Neurobiol Dis. 2012;46:19-29. https://doi. org/10.1016/j.nbd.2011.12.009.

119. Isosomppi J, Vesa J, Jalanko A, Peltonen L. Lysosomal localization of the neuronal ceroid lipofuscinosis CLN5 protein. Hum Mol Genet. 2002;11:88591. https://doi.org/10.1093/hmg/11.8.885.

120. Lyly A, Von Schantz C, Heine C, Schmiedt ML, Sipilä T, Jalanko A, et al. Novel interactions of CLN5 support molecular networking between Neuronal Ceroid Lipofuscinosis proteins. BMC Cell Biol. 2009;10:83. https://doi.org/10. 1186/1471-2121-10-83.

121. Mamo A, Jules F, Dumaresq-Doiron K, Costantino S, Lefrancois S. The role of ceroid lipofuscinosis neuronal protein 5 (CLN5) in endosomal sorting. Mol Cell Biol. 2012;32:1855-66. https://doi.org/10.1128/MCB.06726-11.

122. Markmann S, Thelen M, Cornils K, Schweizer M, Brocke N, Willnow T, et al. Lrp1/ LDL receptor play critical roles in mannose 6-phosphate-independent lysosomal enzyme targeting. Traffic. 2015;16:743-59. https://doi.org/10.1111/tra.12284.

123. Gao H, Boustany RM, Espinola JA, Cotman SL, Srinidhi L, Antonellis KA, et al. Mutations in a novel CLN6-encoded transmembrane protein cause variant neuronal ceroid lipofuscinosis in man and mouse. Am J Hum Genet. 2002; 70:324-235. https://doi.org/10.1086/338190.

124. Heine C, Quitsch A, Storch S, Martin Y, Lonka L, Lehesjoki AE, et al. Topology and endoplasmic reticulum retention signals of the lysosomal storage disease-related membrane protein CLN6. Mol Membr Biol. 2007:24:74-87. https://doi.org/10.1080/09687860600967317

125. Mole SE, Michaux G, Codlin S, Wheeler RB, Sharp JD, Cutler DF. CLN6, which is associated with a lysosomal storage disease, is an endoplasmic reticulum protein. Exp Cell Res. 2004;298:399-406. https://doi.org/10. 1016/j.yexcr.2004.04.042

126. Alroy J, T. Braulke, IA, Cismondi JD, Cooper D, Creegan et al. S. Mole, R. Williams, H. Goebel (Eds.), Cln6. The Neuronal Ceroid Lipofuscinoses (Batten Disease), 2nd ed., Oxford University Press, 2011; pp. 159-175.

127. Holopainen JM, Saarikoski J, Kinnunen PK, Järvelä IE. Elevated lysosomal pH in neuronal ceroid lipofuscinoses (NCLs). Eur J Biochem. 2001;268:5851-6. https://doi.org/10.1046/j.0014-2956.2001.02530.x.

128. Thelen M, Damme M, Schweizer M, Hagel C, Wong AM, Cooper JD, et al. Disruption of the autophagy-lysosome pathway is involved in 
neuropathology of the nclf mouse model of neuronal ceroid lipofuscinosis. PLoS One. 2012;7:e35493. https://doi.org/10.1371/journal.pone.0035493.

129. Sleat DE, Lackland H, Wang Y, Sohar I, Xiao G, Li H, et al. The human brain mannose 6-phosphate glycoproteome: a complex mixture composed of multiple isoforms of many soluble lysosomal proteins. Proteomics. 2005;5: 1520-32. https://doi.org/10.1002/pmic.200401054.

130. Bolognin S, Messori L, Zatta P. Metal ion physiopathology in neurodegenerative disorders. Neuromolecular Med. 2009;11:223-38. https:// doi.org/10.1007/s12017-009-8102-1.

131. Kanninen KM, Grubman A, Meyerowitz J, Duncan C, Tan JL, Parker SJ, et al. Increased zinc and manganese in parallel with neurodegeneration, synaptic protein changes and activation of Akt/GSK3 signaling in ovine CLN6 neuronal ceroid lipofuscinosis. PLoS One. 2013;8:e58644. https://doi.org/10. 1371/journal.pone.0058644.

132. Aiello C, Terracciano A, Simonati A, Discepoli G, Cannelli N, Claps D, et al. Mutations in MFSD8/CLN7 are a frequent cause of variant-late infantile neuronal ceroid lipofuscinosis. Hum Mut. 2009;30:E530-40. https://doi.org/ 10.1002/humu.20975.

133. Sharifi A, Kousi M, Sagné C, Bellenchi GC, Morel L, Darmon M, et al. Expression and lysosomal targeting of CLN7, a major facilitator superfamily transporter associated with variant late-infantile neuronal ceroid lipofuscinosis. Hum. Mol. Genet. 2010;19:4497-514. https://doi.org/10.1093/ $\mathrm{hmg} / \mathrm{ddq} 381$

134. Schröder B, Wrocklage C, Pan C, Jäger R, Kösters B, Schäfer H, et al. Integral and associated lysosomal membrane proteins. Traffic. 2007;8:1676-86. https://doi.org/10.1111/j.1600-0854.2007.00643.x.

135. Steenhuis P, Herder S, Gelis S, Braulke T, Storch S. Lysosomal targeting of the CLN7 membrane glycoprotein and transport via the plasma membrane require a dileucine motif. Traffic. 2010;11:987-1000. https://doi.org/10.1111/j. 1600-0854.2010.01073.x.

136. Brandenstein L, Schweizer M, Sedlacik J, Fiehler J, Storch S. Lysosomal dysfunction and impaired autophagy in a novel mouse model deficient for the lysosomal membrane protein Cln7. Hum Mol Genet. 2016;25:777-91. https://doi.org/10.1093/hmg/ddv615.

137. Danyukova T, Ariunbat K, Thelen M, Brocke-Ahmadinejad N, Mole SE, Storch S. Loss of CLN7 results in depletion of soluble lysosomal proteins and impaired mTOR reactivation. Hum Mol Genet. 2018;19:4497-514. https://doi. org/10.1093/hmg/ddy076.

138. Ranta S, Zhang Y, Ross B, Lonka L, Takkunen E, Messer A, et al. The neuronal ceroid lipofuscinoses in human EPMR and mnd mutant mice are associated with mutations in CLN8. Nat Genet. 1999;23:233-6. https:/doi.org/10.1038/13868.

139. Lonka L, Kytälä A, Ranta S, Jalanko A, Lehesjoki AE. The neuronal ceroid lipofuscinosis CLN8 membrane protein is a resident of the endoplasmic reticulum. Hum Mol Genet. 2000;9:1691-7. https://doi.org/10.1074/jbc.M400643200.

140. Messer A, Plummer J, MacMillen MC, Frankel WN. Genetics of primary and timing effects in the mnd mouse. Am J Med Genet. 1995;57:361-4. https:// doi.org/10.1002/ajmg.1320570251.

141. Lonka L, Aalto A, Kopra O, Kuronen M, Kokaia Z, Saarma M, et al. The neuronal ceroid lipofuscinosis Cln8 gene expression is developmentally regulated in mouse brain and up-regulated in the hippocampal kindling model of epilepsy. BMC Neurosci. 2005;6:27. https://doi.org/10.1186/14712202-6-27.

142. Haddad SE, Khoury M, Daoud M, Kantar R, Harati H, Mousallem T, et al. CLN5 and CLN8 protein association with ceramide synthase: biochemical and proteomic approaches. Electrophoresis. 2012;33:3798-809. https://doi. org/10.1002/elps.201200472.

143. Hermansson M, Käkelä R, Berghäll M, Lehesjoki AE, Somerharju P, Lahtinen U. Mass spectrometric analysis reveals changes in phospholipid, neutral sphingolipid and sulfatide molecular species in progressive epilepsy with mental retardation, EPMR, brain: a case study. J Neurochem. 2005;95:609-17. https://doi.org/10.1111/j.1471-4159.2005.03376.x.

144. Zhang CK, Stein PB, Liu J, Wang Z, Yang R, Cho JH, et al. Genome-wide association study of N370S homozygous Gaucher disease reveals the candidacy of CLN8 gene as a genetic modifier contributing to extreme phenotypic variation. Am J Hematol. 2012;87:377-83. https://doi.org/10.1002/ajh.23118.

145. Galizzi G, Russo D, Deidda I, Cascio C, Passantino R, Guarneri R, et al. Different early ER-stress responses in the CLN8(mnd) mouse model of neuronal ceroid lipofuscinosis. Neurosci Lett. 2011;488:258-62. https://doi. org/10.1016/j.neulet.2010.11.041.

146. Guarneri R, Russo D, Cascio C, D'Agostino S, Galizzi G, Bigini G, et al. Retinal oxidation, apoptosis and age- and sex-differences in the mnd mutant mouse, a model of neuronal ceroid lipofuscinosis. Brain Res. 2004;1014:209-20. https://doi.org/10.1016/j.brainres.2004.04.040.

147. Kolikova J, Afzalov R, Surin A, Lehesjoki AE, Khiroug L. Deficient mitochondrial $\mathrm{Ca} 2+$ buffering in the $\mathrm{Cln} 8(\mathrm{mnd})$ mouse model of neuronal ceroid lipofuscinosis. Cell Calcium. 2011;50:491-501. https://doi.org/10.1016/j.ceca.2011.08.004.

148. di Ronza A, Bajaj L, Sharma J, Sanagasetti D, Lotfi P, Adamski CJ, et al. CLN8 is an endoplasmic reticulum cargo receptor that regulates lysosome biogenesis. Nat Cell Biol. 2018. https://doi.org/10.1038/s41556-018-0228-7.

149. Siintola E, Partanen S, Strömme P, Haapanen A, Haltia M, Maehlen J, et al. Cathepsin D deficiency underlies congenital human neuronal ceroidlipofuscinosis. Brain. 2006;129:1438-45. https://doi.org/10.1093/brain/awl107.

150. Steinfeld R, Reinhardt K, Schreiber K, Hillebrand M, Kraetzner R, Bruck W, et al. Cathepsin D deficiency is associated with a human neurodegenerative disorder. Am J Hum Genet. 2006;78:988-98. https://doi.org/10.1086/504159.

151. Benes P, Vetvicka V, Fusek M. Cathepsin D-Many functions of one aspartic protease. Crit Rev Oncol Hematol. 2008;68:12-28. https://doi.org/10.1016/j. critrevonc.2008.02.008.

152. Sevlever D, Jiang P, Yen SH. Cathepsin D is the main lysosomal enzyme involved in the degradation of alpha-synuclein and generation of its carboxy-terminally truncated species. Biochemistry. 2008;47:9678-87. https:// doi.org/10.1021/bi800699v

153. Doccini S, Sartori S, Maeser S, Pezzini F, Rossato S, Moro F, et al. Early infantile neuronal ceroid lipofuscinosis (CLN10 disease) associated with a novel mutation in CTSD. J Neurol. 2016;263:1029-32. https://doi.org/10. 1007/s00415-016-8111-6.

154. Mole SE, Williams RE. In: Pagon RA, Bird TD, Dolan CR, Stephens K, editors. Neuronal ceroid-lipofuscinoses. Seattle: Gene Reviews; 1993.

155. Tyynela J, Sohar I, Sleat DE, Gin RM, Donnelly RJ, Baumann M, et al. A mutation in the ovine cathepsin D gene causes a congenital lysosomal storage disease with profound neurodegeneration. EMBO J. 2000;19:278692. https://doi.org/10.1093/emboj/19.12.2786.

156. Awano T, Katz ML, O'Brien DP, Taylor JF, Evans J, Khan S, et al. A mutation in the cathepsin D gene (CTSD) in American Bulldogs with neuronal ceroid lipofuscinosis. Molecular Genetics and Metabolism. 2006;87:341-8. https:// doi.org/10.1016/j.ymgme.2005.11.005.

157. Zaidi N, Maurer A, Nieke S, Kalbacher H. Cathepsin D: a cellular roadmap. Biochem Biophys Res Commun. 2008;376:5-9. https://doi.org/10.1016/j.bbrc.2008.08.099.

158. Cunningham M, Tang J. Purification and properties of cathepsin D from porcine spleen. J Biol Chem. 1976;251:4528-36.

159. Shacka JJ. Mouse models of neuronal ceroid lipofuscinoses: useful preclinical tools to delineate disease pathophysiology and validate therapeutics. Brain Res Bull. 2012;88:43-57. https://doi.org/10.1016/j. brainresbull.2012.03.003.

160. Myllykangas L, Tyynelä J, Page-McCaw A, Rubin GM, Haltia MJ, Feany MB. Cathepsin D-deficient Drosophila recapitulate the key features of neuronal ceroid lipofuscinoses. Neurobiol Dis. 2005;19:194-9. https://doi.org/10.1016/j. nbd.2004.12.019

161. Koike M, Nakanishi H, Saftig P, Ezaki J, Isahara K, Ohsawa Y, et al. Cathepsin $D$ deficiency induces lysosomal storage with ceroid lipofuscin in mouse CNS neurons. J Neurosci. 2000;20:6898-906.

162. Saftig P, Hetman M, Schmahl W, Weber K, Heine L, Mossmann H, et al. Mice deficient for the lysosomal proteinase cathepsin D exhibit progressive atrophy of the intestinal mucosa and profound destruction of lymphoid cells. EMBO J. 1995;14:3599-608 PMID: 7641679.

163. Chandra G, Bagh MB, Peng S, Saha A, Sarkar C, Moralle M, et al. Cln1 gene disruption in mice reveals a common pathogenic link between two of the most lethal childhood neurodegenerative lysosomal storage disorders. Hum Mol Genet. 2015;24:5416-32. https://doi.org/10.1093/hmg/ddv266.

164. Smith KR, Damiano J, Franceschetti S, Carpenter S, Canafoglia L, Morbin M, et al. Strikingly different clinicopathological phenotypes determined by progranulin-mutation dosage. Am J Hum Genet. 2012;90:1102-7. https://doi.org/10.1016/j.ajhg.2012.04.021.

165. Baker M, Mackenzie IR, Pickering-Brown SM, Gass J, Rademakers R, Lindholm C, et al. Mutations in progranulin cause tau-negative frontotemporal dementia linked to chromosome 17. Nature. 2006;442:916-9. https://doi.org/10.1038/nature05016.

166. Cruts M, Gijselinck I, van der Zee J, Engelborghs S, Wils H, Pirici D, et al (2006) Null mutations in progranulin cause ubiquitin-positive frontotemporal dementia linked to chromosome 17q21. Nature 442:920924. https:// https://doi.org/10.1038/nature05017

167. Neumann M, Sampathu DM, Kwong LK, Truax AC, Micsenyi MC, Chou TT, et al. Ubiquitinated TDP-43 in frontotemporal lobar degeneration and 
amyotrophic lateral sclerosis. Science. 2006;314:130-3. https://doi.org/10. 1126/science.1134108.

168. Kao AW, Mckay A, Singh PP, Brunet HEJ. Progranulin, lysosomal regulation and neurodegenerative disease. Nat Rev Neurosci. 2017;18:325-33. https:// doi.org/10.1038/nrn.2017.36.

169. Ward ME, Chen R, Huang HY, Ludwig C, Telpoukhovskaia M, Taubes A, et al. Individuals with progranulin haploinsufficiency exhibit features of neuronal ceroid lipofuscinosis. Sci Transl Med. 2017; 9:pii: eaah5642. https://doi.org/10. 1126/scitranslmed.aah5642

170. Zhang Y, Chen K, Sloan SA, Bennett ML, Scholze AR, O'Keeffe S, et al. An RNA-sequencing transcriptome and splicing database of glia, neurons, and vascular cells of the cerebral cortex. J Neurosci. 2014;34:11929-47. https:// doi.org/10.1523/JNEUROSCI.1860-14.2014.

171. Petoukhov E, Fernando S, Mills F, Shivji F, Hunter D, Krieger C, et al. Activitydependent secretion of progranulin from synapses. J. Cell Sci. 2013;126: 5412-21. https://doi.org/10.1242/jcs.132076.

172. Lui H, Zhang J, Makinson SR, Cahill MK, Kelley KW, Huang HY, et al. Progranulin deficiency promotes circuit- specific synaptic pruning by microglia via complement activation. Cell. 2016;165:921-35. https:/doi.org/ 10.1016/j.cell.2016.04.001

173. Hu F. Sortilin-mediated endocytosis determines levels of the frontotemporal dementia protein, progranulin. Neuron. 2010;68:654. https://doi.org/10.1016/ j.neuron.2010.09.034.

174. Tang W, Lu Y, Tian QY, Zhang Y, Guo FJ, et al. The growth factor progranulin binds to TNF receptors and is therapeutic against inflammatory arthritis in mice. Science. 2011;332(6028):478-84. https:// doi.org/10.1126/science.1199214.

175. Neill T, Buraschi S, Goyal A, Sharpe C, Natkanski E, Schaefer L, et al. EphA2 is a functional receptor for the growth factor progranulin. J Cell Biol. 2016;215: 687-703. https://doi.org/10.1083/jcb.201603079.

176. Nykjaer A, Lee R, Teng KK, Jansen P, Madsen P, Nielsen MS, et al. Sortilin is essential for proNGF-induced neuronal cell death. Nature. 2004;427:843-8. https://doi.org/10.1038/nature02319.

177. Park B, Buti L, Lee S, Matsuwaki T, Spooner E, Brinkmann MM, et al. Granulin is a soluble cofactor for toll-like receptor 9 signaling. Immunity. 2011;34: 505-13. https://doi.org/10.1016/j.immuni.2011.01.018.

178. Tanaka Y, Matsuwaki T, Yamanouchi K, Nishihara M. Increased lysosomal biogenesis in activated microglia and exacerbated neuronal damage after traumatic brain injury in progranulin-deficient mice. Neuroscience. 2013;250: 8-19. https://doi.org/10.1016/j.neuroscience.2013.06.049.

179. Roczniak-Ferguson A, Petit CS, Froehlich F, Qian S, Ky J, Angarola B, Walther $\mathrm{TC}$, et al. The transcription factor TFEB links mTORC1 signaling to transcriptional control of lysosome homeostasis. Sci Signal. 2012;5:ra42. https://doi.org/10.1126/scisignal.2002790.

180. Evers BM, Rodriguez-Navas C, Tesla RJ, Prange-Kiel J, Wasser CR, Yoo KS, et al. Lipidomic and transcriptomic basis of lysosomal dysfunction in progranulin deficiency. Cell Rep. 2017;20:2565-74. https:/doi.org/10.1016/j.celrep.2017.08.056.

181. Paushter DH, Du H, Feng T, Hu F. The lysosomal function of progranulin, a guardian against neurodegeneration. Acta Neuropathol. 2018;136:1-17. https://doi.org/10.1007/s00401-018-1861-8.

182. Ramirez A, Heimbach A, Gründemann J, Stiller B, Hampshire D, Cid LP, et al. Hereditary parkinsonism with dementia is caused by mutations in ATP13A2, encoding a lysosomal type 5 P-type ATPase. Nat. Genet. 2006;38:1184-91. https://doi.org/10.1038/ng1884.

183. Bras J, Verloes A, Schneider SA, Mole SE, Guerreiro RJ. Mutation of the parkinsonism gene ATP13A2 causes neuronal ceroid-lipofuscinosis. Hum Mol Genet. 2012;21:2646-50. https://doi.org/10.1093/hmg/dds089.

184. Usenovic M, Tress E, Mazzulli JR, Taylor JP, Krainc D. Deficiency of ATP13A2 leads to lysosomal dysfunction, alpha-synuclein accumulation, and neurotoxicity. J Neurosci. 2012;32:4240-6. https://doi.org/10.1523/ JNEUROSCI.5575-11.2012

185. Dehay B, Martinez-Vicente M, Caldwell GA, Caldwell KA, Yue Z, et al. Lysosomal impairment in Parkinson's disease. Mov Disord. 2013;28:725-32. https://doi.org/10.1002/mds.25462.

186. Xu Q, Guo H, Zhang X, Tang B, Cai F, Zhou W, et al. Hypoxia regulation of ATP13A2 (PARK9) gene transcription. J Neurochem. 2012;122:251-9. https:// doi.org/10.1111/j.1471-4159.2012.07676.x.

187. Kong SM, Chan BK, Park JS, Hill KJ, Aitken JB, Cottle L, et al. Parkinson's disease-linked human PARK9/ATP13A2 maintains zinc homeostasis and promotes a-Synuclein externalization via exosomes. Hum Mol Genet. 2014; 23:2816-33. https://doi.org/10.1093/hmg/ddu099.
188. Van Veen S, Sørensen DM, Holemans T, Holen HW, Palmgren MG, Vangheluwe P. Cellular function and pathological role of ATP13A2 and related P-type transport ATPases in Parkinson's disease and other neurological disorders. Front Mol Neurosci. 2014;7:48-60. https://doi.org/10. 3389/fnmol.2014.00048.

189. Tang CH, Lee JW, Galvez MG, Robillard L, Mole SE, Chapman HA. Murine cathepsin F deficiency causes neuronal lipofuscinosis and late-onset neurological disease. Mol Cell Biol. 2006;26:2309-16. https://doi.org/10.1128/ MCB.26.6.2309-2316.2006.

190. Smith KR, Dahl HH, Canafoglia L, Andermann E, Damiano J, Morbin M, et al. Cathepsin F mutations cause Type B Kufs disease, an adult-onset neuronal ceroid lipofuscinosis. Hum. Mol. Genet. 2013;22:1417-23. https://doi.org/10. 1093/hmg/dds558.

191. van der Zee J, Mariën P, Crols R, Van Mossevelde S, Dillen L, Perrone F, et al. Mutated CTSF in adult-onset neuronal ceroid lipofuscinosis and FTD. Neurol Genet. 2016;2:e102. https://doi.org/10.1212/NXG.0000000000000102.

192. Shahwan A, Farrell M, Delanty N. Progressive myoclonic epilepsies: a review of genetic and therapeutic aspects. Lancet Neurol. 2005;4:239-48. https:// doi.org/10.1016/S1474-4422(05)70043-0.

193. Wang B, Shi GP, Yao PM, Li Z, Chapman HA, Brömme D. Human cathepsin F. Molecular cloning, functional expression, tissue localization and enzymatic characterization. J Biol Chem. 1998;273:32000-8.

194. Krabichler B, Rostasy K, Baumann M, Karall D, Scholl-Burgi S, Schwarzer C, et al. Novel mutation in potassium channel related gene KCTD7 and progressive myoclonic epilepsy. Ann Hum Genet. 2012;76:326-31. https:// doi.org/10.1111/j.1469-1809.2012.00710.x.

195. Van Bogaert P, Azizieh R, Desir J, Aeby A, De Meirleir L, Laes JF, et al. Mutation of a potassium channel-related gene in progressive myoclonic epilepsy. Ann Neurol. 2007;61:579-86. https://doi.org/10.1002/ana.21121.

196. Fritzius T, Turecek $R$, Seddik R, Kobayashi H, Tiao J, Rem PD, et al. KCTD Hetero-oligomers Confer Unique Kinetic Properties on Hippocampal GABAB Receptor-Induced K+ Currents. J Neurosci. 2017;37:1162-75. https://doi.org/ 10.1523/JNEUROSCI.2181-16.2016.

197. Staropoli JF, Karaa A, Lim ET, Kirby A, Elbalalesy N, Romansky SG, et al. A homozygous mutation in KCTD7 links neuronal ceroid lipofuscinosis to the ubiquitin-proteasome system. Am J Hum Genet. 2012;91:202-8. https://doi. org/10.1016/j.ajhg.2012.05.023.

198. Pinkas DM, Sanvitale CE, Bufton JC, Sorrell FJ, Solcan N, Chalk R, et al. Structural complexity in the KCTD family of Cullin3-dependent E3 ubiquitin ligases. Biochem J. 2017;474:3747-61. https://doi.org/10.1042/BCJ20170527.

199. Lim CY, Zoncu R. The lysosome as a command-and-control center for cellular metabolism. J. Cell Biol. 2016;214:653-64. https://doi.org/10.4161/ auto.19469.

200. Perera RM, Zoncu R. The lysosome as a regulatory Hub. Annu Rev Cell Dev Biol. 2016;32:223-53. https://doi.org/10.1146/annurev-cellbio-11315-125125.

201. Ben-Sahra I, Manning BD. mTORC1 signaling and the metabolic control of cell growth. Curr Opin Cell Biol. 2017:45:72-82. https://doi.org/10.1016/j.ceb. 2017.02.012

202. Settembre C, Medina DL. TFEB and the CLEAR network. Methods Cell Biol. 2015;126:45-62. https://doi.org/10.1016/bs.mcb.2014.11.011.

203. Wolfe DM, Lee JH, Kumar A, Lee S, Orenstein SJ, Nixon RA. Autophagy failure in Alzheimer's disease and the role of defective lysosomal acidification. Eur J Neurosci. 2013:37:1949-61. https://doi.org/10.1111/ejn.12169.

204. Zoncu R, Bar-Peled L, Efeyan A, Wang S, Sancak Y, Sabatini DM. mTORC1 senses lysosomal amino acids through an inside-out mechanism that requires the vacuolar $\mathrm{H}(+)$-ATPase. Science. 2011;334:678-83. https://doi.org/ 10.1126/science. 1207056

205. Wong CO, Palmieri M, Li J, Akhmedov D, Chao Y, Broadhead GT, et al. Diminished mTORC1-dependent JNK activation underlies the neurodevelopmental defects associated with lysosomal dysfunction. Cel Reports. 2015;12:2009-20. https://doi.org/10.1016/j.celrep.2015.08.047.

206. Wei H, Zhang Z, Saha A, Peng S, Chandra G, Quezado Z, et al. Disruption of adaptive energy metabolism and elevated ribosomal p-S6K1 levels contribute to INCL pathogenesis: partial rescue by resveratrol. Hum Mol Genet. 2011;20:1111-21. https://doi.org/10.1093/hmg/ddq555.

207. Hughes AL, Gottschling DE. An early age increase in vacuolar pH limits mitochondrial function and lifespan in yeast. Nature. 2012;492:261-5. https://doi.org/10.1038/nature11654.

208. Zhang Z, Butler JD, Levin SW, Wisniewski KE, Brooks SS, Mukherjee AB. Lysosomal ceroid depletion by drugs: therapeutic implications for a hereditary neurodegenerative disease of childhood. Nat Med. 2001;7:478-84 PMID:11283676. 
209. Levin SW, Baker EH, Zein WM, Zhang Z, Quezado ZM, Miao N, et al. Oral cysteamine bitartrate and $\mathrm{N}$-acetylcysteine for patients with infantile neuronal ceroid lipofuscinosis: a pilot study. Lancet Neurol. 2014;13:777-87. https://doi.org/10.1016/S1474-4422(14)70142-5.

210. Sarkar C, Chandra G, Peng S, Zhang Z, Liu A, Mukherjee AB. Neuroprotection and lifespan extension in Ppt1(-/-) mice by NtBuHA: therapeutic implications for INCL. Nat Neurosci. 2013;16:1608-17. https://doi. org/10.1038/nn.3526

211. Welch EM, Barton ER, Zhuo J, Tomizawa Y, Friesen WJ, Trifillis P, et al. PTC124 targets genetic disorders caused by nonsense mutations. Nature. 2007:447(7140):87-91. https://doi.org/10.1038/nature05756.

212. Sarkar C, Zhang Z, Mukherjee AB. Stop codon read-through with PTC124 induces palmitoyl-protein thioesterases-1 activity, reduces thioester load and suppresses apoptosis in cultured cells from INCL patients. Mol Genet Metab. 2011;104:338-45. https://doi.org/10.1016/j.ymgme.2011.05.021.

213. Miller JN, Chan CH, Pearce DA. The role of nonsense-mediated decay in neuronal ceroid lipofuscinosis. Hum Mol Genet. 2013;22:2723-34. https://doi. org/10.1093/hmg/ddt120.

214. Bouchelion A, Zhang Z, Li Y, Qian H, Mukherjee AB. Mice homozygous for c451C>T mutation in Cln1 gene recapitulate INCL phenotype. Ann Clin Transl Neurol. 2014;1:1006-23. https://doi.org/10.1002/acn3.144.

215. Lu JY, Hu J, Hofmann SL. Human recombinant pamitoyl-protein thioesterases-1 (PPT1) for preclinical evaluation of enzyme replacement therapy for infantile neuronal ceroid lipofuscinosis. Mol Genet Metab. 2010; 99:374-8. https://doi.org/10.1016/j.ymgme.2009.12.002.

216. Dearborn JT, Ramachandran S, Shyng C, Lu JY, Thornton J, Hofmann SL, et al. Histochemical localization of palmitoyl protein thioesterases-1 activity. Mol Genet Metab. 2016;117:210-6. https://doi.org/10.1016/j.ymgme.2015.11.004.

217. Galliani M, Santi M, Del Grosso A, Cecchettini A, Santorelli FM, Hofmann SL, et al. Crosslinked enzyme aggregates as versatile tool for enzyme delivery: Application to polymeric nanoparticles. Bioconjug Chem. 2018. https://doi. org/10.1021/acs.bioconjchem.8b00206.

218. Macauley SL, Wong AM, Shyng C, Augner DP, Dearborn JT, Pearse Y, et al. An anti-neuroinflammatory that targets dysregulated glia enhances the efficacy of CNS-directed gene therapy in murine infantile neuronal ceroid lipofuscinosis. J Neurosci. 2014;34:13077-82. https://doi.org/10.1523/ JNEUROSCI.2518-14.2014.

219. Shyng C, Nelvagal HR, Dearborn JT, Tyynelä J, Schmidt RE, Sands MS, et al. Synergistic effects of treating the spinal cord and brain in CLN1 disease. Proc Natl Acad Sci U S A. 2017;114:E5920-9. https://doi.org/10.1073/pnas. 1701832114.

220. Schultz ML, Tecedor L, Lysenko E, Ramachandran S, Stein CS, Davidson BL. Modulating membrane fluidity corrects Batten disease phenotypes in vitro and in vivo. Neurobiol Dis. 2018;115:182-93. https://doi.org/10.1016/j.nbd. 2018.04.010

221. Wong AM, Rahim AA, Waddington SN, Cooper JD. Current therapies for the soluble lysosomal forms of neuronal ceroid lipofuscinosis. Biochem Soc Trans. 2010:38:1484-8. https://doi.org/10.1042/BST0381484.

222. Hawkins-Salsbury JA, Cooper JD, Sands MS. Pathogenesis and therapies for infantile neuronal ceroid lipofuscinosis (infantile CLN1 disease). Biochim Biophys Acta. 2013;1832(11):1906-9. https://doi.org/10.1016/.jbbadis.2013.05.026.

223. Cotman SL, Mole SE, Kohan R. Future perspectives: Moving towards NCL treatments. Biochim Biophys Acta. 1852;2015:2336-8. https://doi.org/10. 1016/j.bbadis.2015.04.001.

224. Neverman NJ, Best HL, Hofmann SL, Hughes SM. Experimental therapies in the neuronal ceroid lipofuscinoses. Biochim Biophys Acta. 2015;1852:2292-300. https://doi.org/10.1016/j.bbadis. 2015. 04.026.

225. Kleine Holthaus SM, Smith AJ, Mole SE, Ali RR. Gene therapy approaches to treat the neurodegeneration and visual failure in neuronal ceroid lipofuscinoses. Adv Exp Med Biol. 2018;1074:91-9. https://doi.org/10.1007/ 978-3-319-75402-4 12

226. Schulz A, Ajayi T, Specchio N, de Los RE, Gissen P, Ballon D, et al. CLN2 Study Group. Study of intraventricular cerliponase Alfa for CLN2 disease. N Engl J Med. 2018;378:1898-907. https://doi.org/10.1056/NEJMoa1712649.

227. Kinarivala N, Trippier PC. Progress in the development of small molecule therapeutics for the treatment of neuronal ceroid lipofuscinoses (NCLs). J Med Chem. 2016;59:4415-27. https://doi.org/10.1021/acs.jmedchem.5b01020.

228. Bond M, Holthaus SM, Tammen I, Tear G, Russell C. Use of model organisms for the study of neuronal ceroid lipofuscinosis. Biochim Biophys Acta. 2013; 1832:1842-65. https://doi.org/10.1016/j.bbadis.2013.01.009.

\section{Ready to submit your research? Choose BMC and benefit from}

- fast, convenient online submission

- thorough peer review by experienced researchers in your field

- rapid publication on acceptance

- support for research data, including large and complex data types

- gold Open Access which fosters wider collaboration and increased citations

- maximum visibility for your research: over $100 \mathrm{M}$ website views per year

At $\mathrm{BMC}$, research is always in progress.

Learn more biomedcentral.com/submissions 